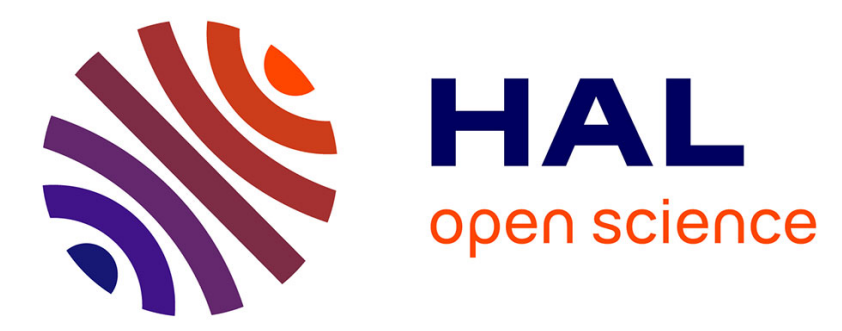

\title{
Does fiscal decentralization enhance citizens' access to public services and reduce poverty? Evidence from Côte d'Ivoire municipalities in a conflict setting
}

Tiangboho Sanogo

\section{- To cite this version:}

Tiangboho Sanogo. Does fiscal decentralization enhance citizens' access to public services and reduce poverty? Evidence from Côte d'Ivoire municipalities in a conflict setting. World Development, 2019, 113, pp.204 - 221. 10.1016/j.worlddev.2018.09.008 . hal-01875189

\author{
HAL Id: hal-01875189 \\ https://hal.science/hal-01875189
}

Submitted on 12 Nov 2021

HAL is a multi-disciplinary open access archive for the deposit and dissemination of scientific research documents, whether they are published or not. The documents may come from teaching and research institutions in France or abroad, or from public or private research centers.
L'archive ouverte pluridisciplinaire HAL, est destinée au dépôt et à la diffusion de documents scientifiques de niveau recherche, publiés ou non, émanant des établissements d'enseignement et de recherche français ou étrangers, des laboratoires publics ou privés. 
Development

Manuscript Draft

Manuscript Number: WD-8756R2

Title: Does fiscal decentralization enhance citizens' access to public services and reduce poverty? Evidence from Côte d'Ivoire municipalities in a conflict setting

Article Type: Manuscript

Keywords: Fiscal decentralization, local tax and non-tax revenues, multidimensional poverty, Local development, Côte d'Ivoire

Corresponding Author: Mr. Tiangboho Sanogo, Ph.D

Corresponding Author's Institution: CERDI

First Author: Tiangboho Sanogo, Ph.D

Order of Authors: Tiangboho Sanogo, Ph.D

Abstract: Fiscal decentralization has been implemented in many countries with an explicit objective of improving public service delivery and reduce poverty. However, its effectiveness in achieving these goals is much debated and the empirical literature has mostly focused on poverty reduction using cross-country analysis.

This paper analyses whether, and how, the devolution of revenue raising responsibilities to Côte d'Ivoire' municipalities enhances access to public services and contributes to reducing poverty. Local revenue sources that reflect municipalities' autonomy in decision-making are considered to measure revenue decentralization. An adjusted multidimensional poverty index for access to public services and a headcount poverty index are also calculated at the local level using the Household Living Standard Survey. The empirical analysis uses a grouped fixed effect approach, combined with a two-stage least squares methodology with panel corrected standard errors clustered by département to address both time-varying heterogeneity and local revenue endogeneity. Our study finds that increased local revenue positively affects access to public services and reduces poverty. However, there is evidence that revenue decentralization has a more robust effect on access to public service, than on poverty. This effect seems to work mainly through enhancing access to education more than access to health, water, and sanitation services. Interestingly, our results indicate that municipalities are more likely to improve access to public services in less ethnically diverse localities and in urban zones. The study shows that the conflict has compounded the existing problems of access to public services with no statistically significant effect on poverty. 
Does fiscal decentralization enhance citizens' access to public services and reduce poverty? Evidence from Côte d'Ivoire municipalities in a conflict setting

\section{Tiangboho Sanogo}

CERDI- University of Clermont Auvergne, France Tiangboho.sanogo@uca.fr

\section{Tiangboho.sanogo@yahoo.fr}

Hard mail address: 25 Rue Etienne Dolet, 63000 Clermont Ferrand, France

Phone contact : +336 65541554

Tiangboho Sanogo is a PhD Candidate and a Teaching Assistant at the Centre d'Etudes et de Recherches sur le Développement International (CERDI), University Clermont Auvergne, France. He is an Independent Tax Consultant at the time of writing the paper. 

5 Fiscal decentralization has been implemented in many countries with an explicit objective of 6

\section{Abstract} improving public service delivery and reduce poverty. However, its effectiveness in achieving these goals is much debated and the empirical literature has mostly focused on poverty reduction using cross-country analysis.

This paper analyses whether, and how, the devolution of revenue raising responsibilities to 16 Côte d'Ivoire' municipalities enhances access to public services and contributes to reducing poverty. Local revenue sources that reflect municipalities' autonomy in decision-making are 21 considered to measure revenue decentralization. An adjusted multidimensional poverty index for access to public services and a headcount poverty index are also calculated at the local level using the Household Living Standard Survey. The empirical analysis uses a grouped 28 fixed effect approach, combined with a two-stage least squares methodology with panel corrected standard errors clustered by département to address both time-varying heterogeneity and local revenue endogeneity.

Our study finds that increased local revenue positively affects access to public services and 38 reduces poverty. However, there is evidence that revenue decentralization has a more robust 
effect on access to public service, than on poverty. This effect seems to work mainly through

enhancing access to education more than access to health, water, and sanitation services. 45

Interestingly, our results indicate that municipalities are more likely to improve access to

public services in less ethnically diverse localities and in urban zones. The study shows that 50 the conflict has compounded the existing problems of access to public services with no statistically significant effect on poverty.

\section{*Acknowledgements}

\section{Acknowledgements}

The author would like to thank Jean-François Brun (CERDI) and Antonio Savoia (University of Manchester) for helpful comments. This work was supported by the LABEX IDGM+ (ANR-10-LABX-14-01) within the program "Investissements d'Avenir" operated by the French National Research Agency. The data construction has been supported by the International Centre for Tax and Development in the UK under the project no. GO/12001. This paper has also benefited from discussions at the Centre for European Economic Research (ZEW) Conference on Public Finance and Development (Germany, Mannheim, May 2017). I also wish to thank the participants in the Gates Foundation and University of Oxford Workshop on Public Finance in Developing Countries hosted by Johns Hopkins University (Washington D.C, November 2017), for useful suggestions.

I am greatly indebted to the officials at "la Tutelle Economique et Financière (D.T.E.F) de la 
Direction Générale de la Décentralisation”, and selected municipalities in Côte d'Ivoire, for facilitating access to data and relevant documents.

I also thank the anonymous referees for extensive comments. Any remaining errors are mine.

\section{Highlights}

$\square$ Increasing municipal-raised revenues improve access to public services and reduce poverty.

$\square$ Revenue decentralization has a more robust effect on access to public service, than on poverty.

$\square$ This effect works mainly through enhancing access to education than on access to health. 
$19 \square$ Local heterogeneity and urbanization play a key role in access to public services. 20

$\square$ The conflict has compounded the existing problems of access to public services. 



\section{Abstract}

Fiscal decentralization has been implemented in many countries with an explicit objective of

improving public service delivery and reduce poverty. However, its effectiveness in achieving 6

these goals are much debated and the empirical literature has mostly focused on poverty 8 reduction using cross-country analysis.

This paper analyses whether, and how, the devolution of revenue raising responsibilities to Côte 13

d'Ivoire' municipalities enhances access to public services and contributes to reducing poverty.

Local revenue sources that reflect municipalities' autonomy in decision-making are considered 18

to measure revenue decentralization. An adjusted multidimensional poverty index for access to

public services and a headcount poverty index are also calculated at the local level using the 23

Household Living Standard Survey. The empirical analysis uses a grouped fixed effect approach,

combined with a two-stage least squares methodology with panel corrected standard errors

clustered by département to address both time-varying heterogeneity and local revenue 30

endogeneity.

Our study finds that increased local revenue positively affects access to public services and 35

reduces poverty. However, there is evidence that revenue decentralization has a more robust

effect on access to public service, than on poverty. This effect seems to work mainly through 40

enhancing access to education more than access to health, water, and sanitation services. 
services in less ethnically diverse localities and in urban zones. The study shows that the conflict 47 has compounded the existing problems of access to public services with no statistically

Interestingly, our results indicate that municipalities are more likely to improve access to public (1) (1)

significant effect on poverty.

54

Keywords - fiscal decentralization, local tax and non-tax revenues, multidimensional poverty,

Local development, Côte d'Ivoire 


\section{Introduction}

Over the past decades, fiscal decentralization has been implemented by an increasing number of African countries, with an explicit objective of improving public service delivery, becoming thus a key public-sector reform (Gradstein, 2017; Kis-Katos \& Sjahrir, 2017; Ramírez, Díaz, \&

10 Bedoya, 2017; Rodríguez-Pose \& Ezcurra, 2010) ${ }^{1}$. This interest has stemmed largely from a 11 
citizens is often too limited to apply sufficient political pressure (Bardhan \& Mookherjee, 2005), 21 local authorities are likely to be under pressure from elites (R. Bird \& Rodriguez, 1999) and

prone to corruption (Prud'homme 1995). In sub-Saharan Africa, there is little empirical evidence

on the effects of fiscal decentralization on poverty and the delivery of public services such as 28

education and health, especially focusing on one country ${ }^{2}$.

This paper contributes to the literature by analyzing whether revenue decentralization, measured 33

as the ratio of municipal own revenues to total revenues, improves the access to public services

and reduces poverty in Côte d'Ivoire conflict setting, over the period 2001-2011.

The issue is particularly relevant for Côte d'Ivoire, where $35 \%$ of the population are deprived of basic services (Alkire \& Santos, 2014) and where marked income disparities exist among

regions ${ }^{1}$. The country is an interesting case study for three main reasons. One, responsibilities in 45 raising local taxes and delivering services such as education, health, roads and drinking water have been devolved to municipalities, though the central government still plays a crucial role in

\footnotetext{
${ }^{1}$ While there are municipalities where internally collected revenues represent almost $90 \%$ of their total revenue, other municipalities depend on central transfers at more than 70\% (Brun \& Sanogo, 2017).
} 
${ }^{1}$ Although the implementation of fiscal decentralization reforms often remains incomplete (Joanis, 2014) and there is a difference between countries "announcement" of embarking and the real implementation of the process. ${ }^{2}$

The term poverty refers only to monetary poverty in this paper.

ensuring citizens' access to services. Second, the country has a large ethnic diversity of different culture and preferences, which heterogeneity might be of interest for fiscal decentralization reforms. In addition, the relationship between fiscal decentralization and poverty is particularly ambiguous in a fragile context such as Côte d'Ivoire, as the conflict, that the country experienced, has compounded the existing problems of access to public services and has

poverty are ambiguous. One strand of this literature argues that the benefits of decentralization 18 stem from inter-jurisdictional competition that should result in higher responsiveness to local

needs (Tiebout, 1959). Through this idea, based on the mobility of citizens across local jurisdictions and the resulting electoral pressures, decentralization enhances accountability of local governments in the service delivery (Bardhan \& Mookherjee, 2005). In developing countries, this mechanism might not work because citizen's mobility is often limited (Bardhan, 30 2002). Decentralization is also claimed to improve service provision efficiency by providing informational advantages to local governments (Hayek, 1945; Oates, 1993). Local government 35 
environment for local development (Tranchant, 2007), particularly in the countries of high ethnic 40 heterogeneity or regional identities (Faguet 2014). Numerous other studies have stressed the

benefits from decentralization regarding access to public services and poverty reduction 45

(Hindriks, Peralta, \& Weber, 2008; Weingast, 2014), but for a country to gain from improved 47 efficiency, the local democracy must function effectively and local authorities must have

substantial revenue autonomy and power in allocating resources (Oates, 1993). In developing 52 countries, however, there are strong reasons to believe that such presumptions are violated 54 (Smoke, 2001).

Against these advantages, Prud'homme (1995) and Treisman (1997), among others, suggest that decentralization may worsen delivery of public services. Tax decentralization might increase inequality among regions due to the different tax potential of regions and the competition between jurisdictions that could result in reduced tax rates to attract investments and subsequent loss of efficiency in the delivery of public services (Treisman, 2000). Local elites' capture in the

decision-making process (Bardhan \& Mookherjee, 2000) might increase income inequality since 13 local revenue collection favors a minority of high-income individuals (Martinez-Vazquez \& McNab, 2003). Heterogeneity of the population in developing countries is mostly based on income, rather than difference in tastes. The priorities are therefore to satisfy the population's 
basic needs, which are better managed by central government (Prud'homme 1995).

The empirical evidence on the effects of fiscal decentralization and poverty reduction and access to public services delivery are also inconclusive. While Gonçalves (2014) finds that local citizens' participation in service provision contributes to improving infant mortality and reducing 30 poverty in Brazilian municipalities, Galiani, Gertler, \& Schargrodsky (2008) suggest that it increases inequalities in the provision of education services in Argentina. One potential 35 explanation is that local elites can capture public resources to their preferred uses (Reinikka \&

Svensson, 2004) and thus limit the scope of local populations monitoring initiatives (Olken, 40

2007). Similarly, Francis \& James (2003) conclude that decentralization in Uganda failed to

reduce poverty because of local governments capture by local elites. Local institutions decision 45

making accounts for cultural values and therefore helps to reduce rural poverty in Burkina Faso 47

(Donnelly-Roark, Ouedraogo, \& Ye, 2001). In India, active involvement of local authorities

allows a better targeting of beneficiaries for poverty eradication programs in Kerala (Heller, 52

Harilal, \& Chaudhuri, 2007). Many research find a positive effect of fiscal decentralization on

poverty and access to public services (Emilie Caldeira, Martial, \& Rota-Graziozi, 2012; Cavalieri \& Ferrante, 2016; Faguet \& Sánchez, 2008), while others report opposite results (Bahiigwa, Rigby, \& Woodhouse, 2005).

Local heterogeneity is found to play a key role in these mixed evidences (R. M. Bird \& 
Vaillancourt, 2006). For example, Alesina, Baqir, \& Easterly (1999) find ethnic diversity reduces the performance of city government in delivering public services in America. And regional

studies using country-level data have analyzed this relationship, especially in sub-Saharan 18

Africa, ignoring thus the institutional arrangements that govern the design and implementation of decentralization (Ramírez et al., 2017; von Braun \& Grote, 2000).

This study analyses how revenue decentralization to municipalities affects access to public services and poverty in Côte d'Ivoire. Local revenue sources that reflect municipalities' 28 autonomy in decision-making are considered. Contrary to Ramírez et al., (2017), who leave aside 30 monetary poverty, this paper considers both access to public service, measured using an adjusted

multidimensional poverty index (MPIa) and a headcount poverty index (HPIn) calculated as the 35 ratio of population living with less than US $\$ 1$ a day to total population of each locality. The paper assesses also whether the effects of revenue decentralization vary between local governments according to their internal heterogeneity, defined as the degree of ethnic

fractionalization and polarization. The analysis accounts for the potential effects of conflict, which might affect the ability of local governments to raise revenue and provides public services. 
developing country which allows to properly control for country-specific heterogeneity than 52

cross-country studies. The second contribution comes from the improved empirical approach using the Grouped Fixed Effect (GFE) method for estimations and an innovative construction of instruments for endogeneity. The GFE estimator allows controlling for unobservable individual heterogeneity, which may vary or not over time, that cannot be accounted for by the standard fixed effects approach used in previous studies on the effects of decentralization (Bartolucci, Belotti, \& Peracchi, 2015). A two-stage least squares method is combined with the GFE to properly address the potential endogeneity of local revenues.

municipalities aggregated in 35 départements. The overall result shows that local revenues have 13

a positive and significant effect on access to public services which are consistent with the

findings in Colombia by Ramírez et al., (2017) and contradict those in Uganda by Bahiigwa, 18

Rigby, \& Woodhouse (2005). However, there is evidence that revenue decentralization has a

more robust effect on access to public service, rather than poverty. This effect seems to work 23

mainly by increasing access to education more than to health, water, and sanitation services. The

results indicate that municipalities are more likely to improve access to public services in less

ethnically diverse localities and in rural zones. This study provides evidence that effect of the 30 conflict has been statistically limited. 


\section{decentralization process, and the poverty in Côte d'Ivoire with its regional distribution. Section 3}

presents the data and the model specification. The results and the robustness checks are discussed in section 4. Section 5 concludes and provides some policy implications.

\section{Background}

\subsection{Fiscal decentralization in Côte d'Ivoire}

The revenue structure of local government in Côte d'Ivoire is largely inherited from the colonial 52 period. The implementation started with law No. 55-1489 of 18 November 1955 which established municipalities in Abidjan, Bouaké and Grand Bassam for which local authorities did not have financial autonomy. The real commitment of the central government to implement decentralization especially the financial autonomy of municipalities, started with Law No. 801162 of 17 October 1980. This law defined a specific status and electoral regime for municipalities and created 37 municipality councils in addition to Abidjan. The government has spread the reform to other regions by transferring expenditure and revenue raising responsibilities to local authorities with the aim of improving the delivery of public services. 
tiered system with 19 regions sub-divided into 58 départements governed by départements 18 councils, and 197 municipalities. Since 2011, although the number of municipalities has

remained unchanged, the central government has reorganized the country into 14 districts (with 23 full autonomy for Abidjan and Yamoussoukro), 31 regions, 95 départements, and 197

municipalities, each with an elected mayor.

The Ministry of Interior manages the decentralization process through the Directorate in charge 30 of decentralization and local development (DDLD). The Ministry of Economy and Finance

collaborates with the DDLD to define the amounts of transfers from central to local governments 35 and their allocation. These administrations interact with municipalities organized in the

association the Union of Côte d'Ivoire for cities and municipalities. The relationship between 40 central and local governments is organized through a trusteeship system with two levels, by

which the central administration approves decisions and helps municipalities.

In the process of strengthening the fiscal autonomy of municipalities and grassroots participation 47

in the decision-making process, more than 35 legislative decrees and laws have been passed to

assign expenditure execution responsibilities, and revenue raising functions to municipalities. 52 These responsibilities are often related to the provision of important public services such as health and education facilities, water and sanitation, local urbanization, and include large sources of revenue. 
Local own revenue has two main components: non-tax revenue collected exclusively by local tax administration, and tax revenue collected on behalf of local governments by central government through the General Tax Directorate. Although this local non-tax revenue is smaller than local tax revenue, this revenue remains a key element for increasing accountability and tax compliance at the local level. Local non-tax revenue is likely to be used to improves the population's access

to public services as the local authorities have full autonomy in managing this revenue, in 13

contrast to local tax revenue which is often earmarked. 15

4. Over Figure

1 shows the compo sition of total munici pality revenu e over the period 20012014

municipal revenue. This share decreased slightly in the three-year period leading up to the 201023

this period, transfers from the central government contributed on average more than $35 \%$ of total 
national election. ${ }^{2}$ During the same period, municipalities collected a small part of their total revenue, on average less than $20 \%$. However, tax revenue represents on average $25 \%$ of total municipality revenue and remained relatively constant in absolute terms up to 2014. Combining 30 these two components, local own revenue contributed $45 \%$ of total revenue. This is relatively

low compared to other developing countries such as Benin, where municipalities' own revenue contributed 69\% of total revenue over the period 2003 to 2008 (E. Caldeira \& Rota-Graziosi,

2014).

[FIGURE 1]

Figure 2 presents the structure of local non-tax revenue aggregated for the period 2002 to 2007.

Small business revenues and licenses contributes the highest share of local non-tax revenue at

${ }^{4}$ This analysis focuses on the municipal level because there is no recent data on revenue covering all levels of subgovernments in the country (districts, regions, départements, and municipalities).

\footnotetext{
${ }^{2}$ This trend suggests a possible reassignment of resources to election expenditure since the allocation criteria of these transfers remain mostly at the discretion of central government.
} 


\subsection{Public service delivery and poverty trends in Côte d'Ivoire}

In this sub-section, poverty trends are analyzed through both the poverty and the access to public services using respectively the poverty headcount ratio and the multidimensional poverty index 29 (MPI) recently developed by Alkire \& Santos (2010).

Three decades after starting its decentralization process, Côte d'Ivoire remains one of the poorest 34 countries in the world, ranked 171 out of 188 countries according to the 2016 Human

Development Index. Following its independence from France in 1960, the country enjoyed a 39 period of economic growth and political stability driven by agriculture exports, mainly coffee 
and cocoa. At end of the 1970s, the country experienced an economic downturn due to an 44 unexpected drop in the world prices of these export goods. This economic crisis increased the incidence of poverty up to the 1990s (Bargain, Donni, \& Kwenda, 2014). To improve the population access to basic public services, especially in rural areas and thereby reduce regional 51 disparities, the Ivorian government has undertaken a process of fiscal decentralization by involving municipalities in tax raising responsibilities and public services delivery. This shift of responsibilities was followed by a fall in poverty by $3.2 \%$ over the period $1995-1998$.

Unfortunately, the expected results from fiscal decentralization have been limited, due, to three main reasons. First, like in many developing countries, the central government has been reluctant to provide municipalities with considerable responsibilities of tax raising. Second, the administrative capacity of municipalities is very limited in some areas. The third reason is that the country experienced several episodes of conflict $^{3}$, which compounded the existing problems

of access to public services and of poverty. 13

Since the last three decades, the share of the population living under the poverty line has 15 increased significantly. Figure 3 shows the evolution of poverty headcount ratio in percentage of 17 total population from 1985 to 2015 . The poverty rate increased from $10.1 \%$ in 1985 to $48.9 \%$ in 19 2015 (HLSS, 2015). Access to public services also remains limited in the country. The

${ }^{3}$ Since 1999, Côte d'Ivoire has experienced the 1999 "coup d'etat", the 2002 political conflict and the post-electoral conflict of 2010/2011. This period was characterized by sporadic events with different intensity and location (Dabalen et al, 2012). 
multidimensional poverty rate, assessing the privation of citizen in several dimensions of public services, increased from $31.8 \%$ in 2008 to $34.4 \%$ in 2011 (Alkire \& Santos, 2014). There is also a widespread disparity between municipalities in access to public services (Figure 4), and a 26 geographical variation regarding local revenue autonomy (Figure 5) ${ }^{4}$. In urban area, on average 28 $75 \%$ of the population has access to education, health, and sanitation, while this figure is only 30 $30 \%$ in rural areas. The water distribution, education, and health services are poor, especially in the northern and western regions. A possible explanation is a significant populations displacement across the country, as highlighted by Furst et al.(2010). In particular, the conflict35 ridden areas in the north and the west, such as the region of Tonpki (Man) and the Savannah 37 (Korhogo), remain the poorest areas (Figure 4). Minoiu \& Shemyakina (2014) report that $70 \%$ of 39 professional health workers and $80 \%$ of government-paid teachers abandoned their post in the 41 north during the 2002-2007 conflict. This spatial distribution of access to public services could be explained by the low population density in these areas which implies higher transportation costs to access to public services and technology. The poorer regions in the country seem to have 46

less revenue autonomy. Figure 6 shows the distribution of conflict events by département. 48

Reported violence against civilians and battles were located mostly in the northern and western départements and in Abidjan.

\section{[FIGURE 3]}

[FIGURE 4]

\footnotetext{
4 "Hight autonomy" refers to localities those own revenue is higher than $50 \%$ of total revenue, the others are defined as "Low autonomy".
} 
[FIGURE 5]

[FIGURE 6] 10

\section{Empirical analysis}

\subsection{Data}

First, local government revenue and expenditures dataset is constructed from the administrative 18 account of municipalities produced by the Ivorian Ministry of Interior and the Ministry of

Economy. This dataset provides information on own revenue, transfers from central government, and local expenditure for 115 municipalities over the period 2001-2011. Following Grisorio \& 25 Prota (2015), the study measures the degree of revenue decentralization as the ratio of own revenues raised and/or controlled by the municipalities (tax and/or non-tax) to the total revenues. 30 This reflects local revenue autonomy and allows an approximation of municipalities' autonomy in decision-making. A high value for this measure indicates a high degree of fiscal 35 decentralization, since local authorities have decision-making autonomy in using this revenue. ${ }^{8}$

The second source is the 2002 and 2008 Household Living Standard Surveys for Côte d'Ivoire 40 from which the social and demographic indicators are calculated. The $\mathrm{HLSS}^{5}$ is a national survey 42 which provides information on different dimensions of household living conditions. Its design

\footnotetext{
${ }^{5}$ The surveys provide information on household access to several facilities like running water, electricity, health, and education infrastructures. They contain data about whether households own certain durable goods such as fridge, computer, car, etc.
} 
ensures representativeness for the 57 Côte d'Ivoire départements. Approximately 10,800 47

households in 2002 and 13,657 households in 2008 were surveyed in the country (HLSS, 2002,

2008).

${ }^{8}$ Another measure of fiscal decentralization is "vertical imbalance" calculated as the ratio of transfers from central government to municipalities total revenue. It represents the degree to which the local government depends on transfers from central government. A high value of this measure indicates little local financial autonomy.

Additionally, information on the geographical distribution of the population from the National Statistical Institute is used to calculate the density of population and the share of urban population.

Third, conflicts indicators are calculated using data from the Armed Conflict Location and Event Dataset (ACLED) (Raleigh, Linke, Hegre, \& Karlsen, 2010). ACLED contains information on

the exact dates and locations of political violence and type of events weighted with a fatality 13 index ${ }^{10}$. The fatality index measures the intensity of events and represents the number of deaths due to each event. The fatality index varies from one to ten, with ten for the highest incidence of violence, and one for the lowest. 20 sources are combined and aggregated at the départements level 
panel spanning 11 years (2001-2011) for 35 départements of the 57 départements in Côte

d'Ivoire.

\section{How are the dependent variables computed?}

Two dependent variables are used: The headcount poverty index (HPIn) calculated as ratio of 33
${ }^{6}$. Access populatio
$\mathrm{n} \quad$ living with less than US \$ 1 a day to total populatio $\mathrm{n}$ of each départem ent

to public services is measured using the multidimensional poverty index (MPI) method

developed by Alkire \& Santos (2010), which captures a set of direct deprivations experienced by 41

a person or a household at the same time. The MPI basic dimensions are adjusted (MPIa) by 43 using different indicators relevant for each dimension to properly capture those for which

municipalities intervene in terms of public service delivery (Table 1). Based on the Alkire-Foster 48 (AF) dual cut-off methodology, the weights are assigned to household for each of the

\footnotetext{
${ }^{6}$ To allow comparison between the two censuses, the data are corrected for inflation using the national prices deflator index.
} 


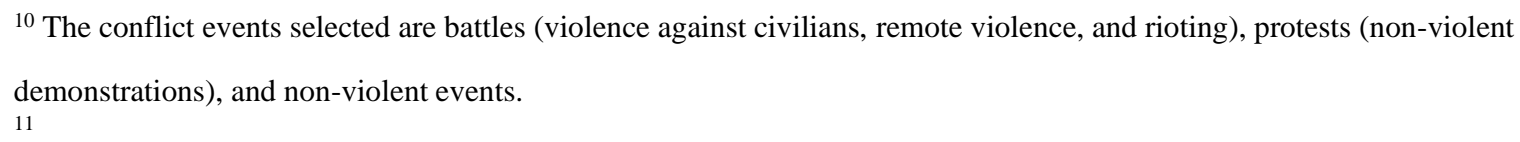

The data are aggregated at départements level because the 2008 HLSS is not available at the municipal level like the first data source. The data are aggregated at départements level because the 2008 HLSS is not available at the municipal level like the first data source.

deprivations and those weights are summed up to generate the weighted deprivations matrix for each household (Alkire \& Foster, 2011; Alkire \& Santos, 2014). A household is considered as deprived of access to public service (in the case of this study) if it has more than $30 \%$ of the weighted sum of the considered dimensions of deprivation (i.e. deprived in some combination of two to six indicators following Alkire \& Santos (2010)). Thus, the ratio of people who are

deprived of public services to total population is calculated for each département. By 13

construction, this indicator has the advantage of being the product of the Headcount $(\mathrm{H})$

(percentage of people whose weighted deprivation lies above the cut-off), and the Average 18 intensity of deprivation (A), which reflects the sum of deprivation for only the

multidimensionally poor households within each département, and thereby the average intensity of poverty for these households.

Table 1 presents the dimensions, indicators, and weights used to compute the MPIa.

There are several reasons for the choice of the dimensions used to calculate MPIa in this 30 analysis. First, local fiscal policies can significantly influence the access to public services for local citizens. Since the 2001 law on decentralization, there has been an ongoing shift of 
responsibility to local governments for education, water, and sanitation, and health services.

\section{[TABLE 1]}

Second, it is easier to interpret, and is well suited for analyzing the access to basic services at 47 local level. The limited number of dimensions simplifies comparison with the HPIn. Third, the

HLSS surveys in Côte d'Ivoire are well documented for the chosen indicators and allow using 52 both the individual and the household as units, which makes the index more accurate than those using only households as units of observation.

The 2002 HLSS is used for the sub-period 2001-2006 while the 2008 HLSS covers the subperiod 2007-2011. The variables constructed from the survey data are thus considered fixed for the periods around the household survey. The main reason is that HLSS is collected only every six to seven years and data from each survey are published within 12 months of the end of field work. To deal with this data scarcity, the study follows Kis-Katos \& Sjahrir (2017) in

considering changes in socio-economic variables as probably limited to be considered and not 13 instantaneous from one year to the next, especially for the main dimensions considered in this

study such adult illiteracy, school-aged child not attending school in years 1 to 8 , access to health 18 services. For example, Deaton (1997) shows that some living standards do not vary in short-term 


\subsection{Model specification}

The previous studies commonly use cross-country data and consider the heterogeneous 43

characteristics as time invariant by using a standard fixed effect approach. One drawback of this 45 method is that the estimates of parameters may be subject to substantial bias in the context that

unobserved heterogeneity is not constant over time (Knight, 2002) ${ }^{7}$. To deal with this problem 50 and account for both varying and unvarying heterogeneity between départements, this analysis

\footnotetext{
${ }^{7}$ For example Knight (2002) by analyzing the impact of Federal Grants on US State Government Spending, argues that some aspects of US states' demands, such as attitudes towards public transport, are unobservable. He finds that a fixed effect may mitigate, but not eliminate this problem.
} 
uses the Grouped Fixed Effect (GFE) approach proposed by Bonhomme \& Manresa (2015). The main motivation for using the GFE method comes from the conflict that the country experienced, which was characterized by a series of events with different intensity and location, as shown by Dabalen et al (2012). As the départements are affected differently by conflict and have different revenue potential, their revenue performance trends could follow different paths based on their

specific unobserved characteristics. Such shocks may induce time-varying unobservable 13

(Bartolucci et al., 2015). Second, the GFE method produces consistent estimates as long as the number of groups is correctly specified, on data that of a short length of time (2001-2011), and which have a

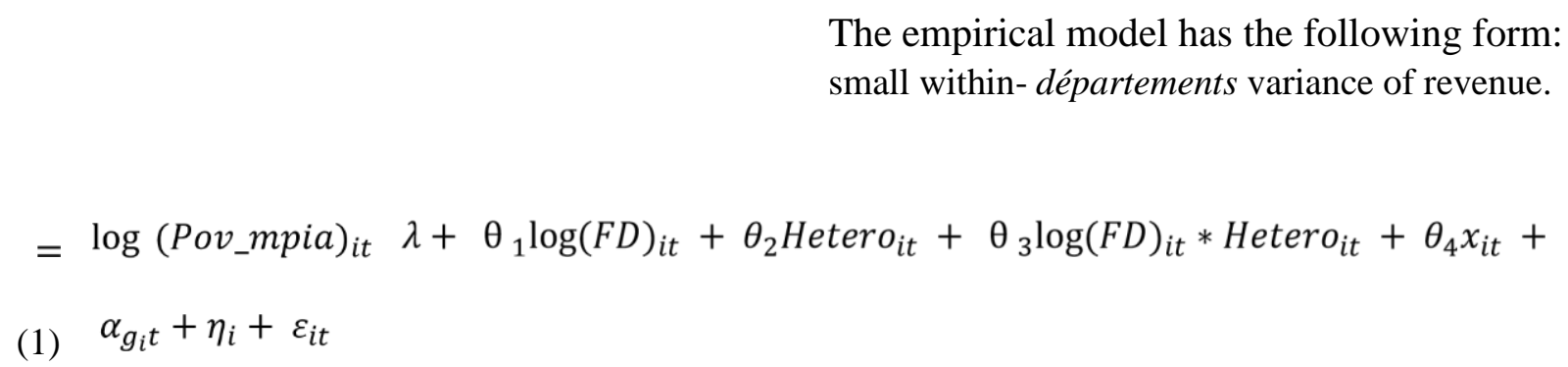

Pov_mpia is the dependent variables $\log (\text { poverty })_{i t}$ or the $\log (M P I a)_{i t r e p r e s e n t i n g}$ respectively the log of the poverty headcount ratio and the adjusted multidimensional poverty index of département $i$ at time $t$. The contribution of education and health in MPI is also used as 37 a dependent variable. It represents the number of habitants who do not have sufficient income or 
randomly selected individuals in a départements will not belong to the same ethnic group.

Following José G. Montalvo \& Reynal-Querol, (2005), ethnic fractionalization is calculated as:

Fractionalization $=\sum_{k=1}^{\mathrm{K}} \phi_{k}\left(1-\phi_{k}\right)$;

Ethnic polarization measures how far the distribution of the ethnic groups is from a bipolar distribution ${ }^{9}$. It is calculated as:

Polarization $=4 \sum_{k=1}^{\mathrm{K}} \phi_{k}^{2}\left(1-\phi_{k}\right)$; Where $\phi_{k}$ Dis the share of population belonging to ethnic

\footnotetext{
${ }^{8}$ The five major ethnic groups are considered: Akan, Krou, Mande North, Mande South and Voltaic. The higher these indices, the stronger the heterogeneity of local demand. Ethnic fractionalization and Ethnic Polarization are calculated based on the 2002 and 2008 surveys and considered fixed for the periods around the household survey. The motivations holding his hypothesis are explained above.

${ }^{9}$ The purpose of the ethnic polarization index is to record how far the distribution of the ethnic groups is from the bipolar distribution. See more in José G. Montalvo \& Reynal-Querol (2005).
} 
group $k$, Kequals total number of ethnic groups the two equations. These variables are assumed 16 to play a key role in the effect of local revenue autonomy on access to basic services and

poverty.

Consistent with existing literature, control variables include transfers from central government,

economic, demographic and social characteristics, represented by $x_{i t}$. The group-specific 26

unobservable effects $\alpha_{g_{i} t}$ is modified to consider the département-specific fixed effect $\eta_{i}$ as 28

${ }^{10}$. The conflict effects are measured through the number of conflict events in each well

département and these numbers are weighted by the fatality index. Conflict variables are

expected to negatively affect the dependent variables.

Before discussing the empirical results, it is necessary to address some issues concerning the 38 estimation strategy. First, there are reasons to consider local own revenue as an endogenous

variable that can induce a bias in estimations. Départements with a high access to services or a 43 low-income poverty rate may have higher potential to increase their revenue collection. The

resulting reverse causality from this relation may bias the estimation results. Moreover, the 48 internal effectiveness of each département in terms of implementing programs and technical staff training are unobservable in the models. This unobservable heterogeneity may be correlated with

\footnotetext{
${ }^{10}$ See appendix B for the definition of the optimal number of groups.
} 

value of the local revenue autonomy ratio instrumental variable is, calculated as:

$$
L R A_{-} I V_{i t}=\frac{1}{\sum_{j-1}^{n} \frac{1}{d_{j}}} \sum_{j-1}^{n} \frac{1}{d_{j}} \text { Ownrev }_{j t} i \neq j
$$
the

ratio of local own revenues to total revenues of département $j$ in year $t$. This instrument is the 23 weighted average of the own revenue ratio for all other départements in the corresponding year,

and the weights are the inverse of the distance between the two département. There are two 28 principles hypotheses holding the use of this instrument as argued by Martinez-Vasquez et al.,

(2011). First, the poverty rate or access to basic services in one département relative to others 33 generally should not influence the local revenue mobilization of other départements, so the dependent variable should not be correlated with the instrument. Second, the design of the own

\footnotetext{
${ }^{11}$ Lee \& Gordon (2005) also use similar way to instrument the corporate tax rate.
} 
revenue raising system in a département should be affected by the design of the own revenue 40

\section{Grouped patterns and consistency of the GFE approach}

A Bayesian Information Criterion (BIC) is used to derive the optimal number of groups that minimize the bias from the estimation of equation $(1)^{12}$. The results in Table A2 (Appendix) suggest that the optimal number of groups according to $\mathrm{BIC}$ is $\mathrm{G}=4$, corresponding to the minimum BIC, which is then used in the GFE estimations throughout the paper. Figure A1

(Appendix) reports the unobserved trends of revenue performance using the four groups, and highlights trends in the group specific effects $\left(\widehat{\boldsymbol{\alpha}}_{\widehat{g} i t}\right)$. Figure A1 shows that the four groups experience unstable trends over time, highlighting the presence of time-varying patterns across the variance of the idiosyncratic disturbance, $K$ the number of parameters of estimation. 
distinct groups in the data that need to be grouped. The left panel shows that the parameter 18

estimated $\widehat{\boldsymbol{\alpha}}_{\widehat{g} i t}$ varies over time which appears to have a high dispersion of groups' patterns in the periods of high incidence of conflict (2002 and 2010). In the right panel, the paths of own revenue differ from one group to another, though groups 2 and 4 seem to follow very similar paths. It is worth noting that the homogenous characteristics within a group remain a critical 28 issue that could be further explored by surveys of local governments.

\section{Empirical results and implications}

Table 2 shows the estimation results of equations 1 concerning the effect of local revenue

autonomy on MPIa or HPIn. As defined above, a negative (positive) sign of a coefficient 40 suggests a positive (negative) impact of the corresponding exogenous variable. All standard

errors are clustered at the département level.

In columns 1 and 7, the results show a positive effect of local revenue autonomy on MPIa and 47 HPIn respectively. This effect is statistically significant for MPIa and insignificant for HPIn.

These results underline the importance of considering poverty as a multidimensional 52 phenomenon which reflects deprivations in multiple dimensions as highlighted by the World 
Once endogeneity is controlled for, municipal revenue autonomy appears to have a positive and 35 statistically significant effect on HPIn at the 5\% level. Comparing this coefficient with those of

\footnotetext{
${ }^{13}$ As noted above, a person is multidimensionally poor if the weighted indicators in which he or she is deprived add up to $30 \%$. This means that the MPIa measures for each locality, the share of population deprived in at least $30 \%$ of the selected dimensions.
}

Bank (2016). Sen (1999) shows that income poverty is limited because welfare can depend on other dimensions such as education, health, and living standards. The difference between the MPIa and HPIn results suggests that municipalities can help reduce deprivations in some dimensions without having significant effects on individuals' income. For example, an individual living under the poverty line and deprived in four dimensions could become deprived in three dimensions due to local government action, but could remain under the poverty line ${ }^{19}$.

Columns 2 and 8 report the GFE estimation results controlling for potential endogeneity of theory that involving local governments in the delivery of public services can help to better account for local demand and improve access to public services.

Column 8 replicates the specification of column 2 by using HPIn as the dependent variable. 
MPIa, the result shows that the coefficient for MPIa is significant at the $1 \%$ level, but HPIn is not significant at the same level. Moreover, the estimated coefficients for other control variables that poverty is uniformly distributed across a given household ignoring the vulnerable family number such as children 54 and old people.

Note that these results are consistent with the theoretical predictions of Oates (1993) and contrast with the findings of Sepulveda \& Martinez-Vazquez (2011) who report that fiscal decentralization increases poverty. The difference between this result and those of Sepulveda and Martinez-Vazquez could be explained by the country-specific context and the method used in their study. Although they use fixed effect estimation, the cross-country regressions might not

account for individual country effects which may affect poverty. Moreover, the log of population 13 and openness to international trade which they use as instruments of fiscal decentralization are

likely to be correlated with both endogenous and dependent variables. This violates the 18 exogenous hypothesis required for valid instrument and could possibly bias estimation results. 
depends on the degree of the heterogeneity of demand. The results for direct effect of ethnic 36 fractionalization and ethnic polarization are reported in columns 3, and 5, for MPIa and in

columns 9 and 11, for HPIn. Columns 4, 6, 10 and, 12 present the interaction of local revenue 41 autonomy crossed with the ethnic fractionalization and polarization index and these level 43 variables in the same specifications for each of MPIa and HPIn. The coefficients for both ethnic

fractionalization and ethnic polarization are negative in the four specifications and significant for 48 columns 5 and 9, highlighting the importance of the homogeneity of local preference in the

satisfaction of local need as predicted. Noteworthy, the coefficients of interaction terms are also 53 negative and significant at 5\% level (columns 5 and 6) only for the MPIa. This suggests that in a less ethnically diverse départements, local authorities have a higher propensity to satisfy citizens in terms of access to public services. In fact, as the literature argues, ethnic diversity has a negative impact on social cohesion and human development (Alesina et al., 1999; Hlepas, 2013). Therefore, the significant effect of heterogeneity of demand on MPIa can be explained by the fact that social cohesion helps to increase of cooperation and maintain social pressure against 
The coefficient for central government transfers is negative, and statistically significant, 41 revealing that transfers from central government to local government contribute to increasing the dependent variable.

statistically significant for the MPI. This indicates that the informal activities negatively affect access to basic services. One explanation might be that informal activities induce loss of revenue 30 for local governments that could have been used for service delivery. However, the coefficients for informal sector are negative, but not significantly different from zero, when taking HPIn as

ccess to public service. This effect may work through the positive incentives transfers create for 46

\footnotetext{
${ }^{14}$ Alesina, Devleeschauwer, Easterly, \& Kurlat (2003) point out the negative effect of ethnic fractionalization on the quality of government.
} 
local governments to provides public services by crowding in local spending (Richard M. Bird \&

Smart, 2002; Bracco, Lockwood, Porcelli, \& Redoano, 2015). Transfers are often used to bridge the gap between spending responsibilities and revenues endowment of municipalities in Côte

d'Ivoire (Brun \& Sanogo, 2017). The share of urban population shows the expected sign. Its coefficient is negative for both MPI and HPIn, suggesting that local governments with a large share of urban populations are likely to improve access to basic services and reduce poverty ${ }^{15}$.

\section{[TABLE 2]}

In table 3, the analysis assumes that MPIa is a good proxy for households' access to basic 10 services, because by design this index represents the deprivation of citizens in several

dimensions of poverty. The estimations show that municipal revenue autonomy has a positive 15 and significant effect on MPIa. However, this result may hide considerable difference in the effect of local revenue autonomy on the different dimensions of poverty (education, health, water-electricity-sanitation, and living standards). To explore this possibility, the contribution of each dimension in MPIa is calculated.

Table 3 presents the results where each dependent variable represents the share of individuals 27 deprived in $30 \%$ of the corresponding dimensions. One might think that there is a significant 
are worth noting. First, it seems that local governments are more likely to increase access to education than to health. The coefficient for education is negative and significant at the $1 \%$ level of significance, and higher than that for health. It is easier for local governments to implement programs for access to education, for example by constructing schools, than for health. For example, local governments are often involved in the provision of public education by village schools although teacher management powers are retained by central government. The devolution of responsibilities in the health sector to municipalities is limited compared to education because of the sensitivity of this sector. This might also be driven by the idea that 13 health services have larger spillovers effects and economies of scale than education services 23. (Besley \& Coate, 2003; Cavalieri \& Ferrante, 2016) 
50 in whether deprived urban and rural populations respond differently to changes in municipal 51

\footnotetext{
16 The literature suggests that, within jurisdictions, there is a large disparity between the urban and rural sectors regarding the access to public services such as education and health (West \& Wong, 1995).
}

to water are not significant. A possible explanation is that, by design, the index concerns the 28

citizens' access to tap water which is the responsibility of central government, which has field 30

offices responsible for delivering water at local level. In columns 10, 11, and 12 about living

standard, which includes cooking fuel, sanitation assets, floor, and electricity, the results are 35 difficult to interpret, since the exogenous instruments are not valid (the Hansen p-value $=0.001$ ).

By design, these dimensions seem less affected by the actions of municipalities.

\section{[TABLE 3]}

In order to identify more clearly the area on which local governments must focus on, the sample 46

16. The analysis is interested is divided into two subgroups: urban population and rural population 
${ }^{23}$ Health prevention initiatives promoted by one jurisdiction are likely to benefit neighbors and the aggregate production and provision of health services, and the joint administration of healthcare structures such as hospitals may not perfectly prompt for a fiscal decentralized solution (Cavalieri \& Ferrante, 2016).

revenue autonomy. All variables in table 3 are included in specifications 1 and 3 respectively for rural and urban populations MPIa index. In table 4, the results are consistent with the previous findings, however there is a significant difference between the two subgroups. The coefficients for municipal revenue autonomy for urban populations are higher than those for rural populations. This suggests that local governments are more likely to reduce deprivation in access

\section{Does conflict affect access to services and poverty? 30}

the period being studied. It is therefore reasonable to Côte d'Ivoire experienced a conflict over

think that this context may have negatively affected the local government capacity to implement 35

rural areas because of low population density and lower relative levels of per capita income which may limit the actions of local governments compared to urban areas.

\section{[TABLE 4]}


programs of poverty reduction and increase in access to public services. To deal with this

possibility, the conflict effect is controlled for through an index represented by the number of 40 conflict events weighted with a fatality index for each event by locality. The fatality index

reports the annual number of deaths due to each event, it varies from one to 10 with 10 for the highest incidence of violence, and one the lowest $\mathrm{t}^{25} .47$

The estimated coefficients are negative and not statistically significant for HPIn. The coefficient of conflict event for MPIa is, however significant at 5\% level of significance (Table 5). This

${ }^{25}$ The conflict data used is an annual data that codes the dates and locations of all reported political violence and protest events over the period being studied in Côte d'Ivoire. An alternative measures of conflict can either be the onset or the duration of conflict event as suggested by Murshed \& Tadjoeddin (2009). Those are not available in the ACLED data for Côte d'Ivoire.

suggests that conflict may have compounded the existing problems of access to public services with no statistically significant effect on poverty. The conflict may have affected municipal administrations which faced problems of their staff and the staff of local services displacement such as education and health. As shown in figure 6, the conflict was characterized by several short periods of conflict events with different intensity and location. A large part of départements

has been affected by conflict with a higher incidence of violence concentrated in the rebel-held, 13

safe locations. 


\section{Are the instruments valid and relevant?}

A relevant econometric issue when addressing endogeneity is whether the excluded exogenous 30 variables are valid instruments. To address this issue, for all specifications, the p-value for the

Hansen over-identification test is reported. The null hypothesis is that the excluded exogenous 35 variables are valid. The reported Hansen p-values are higher than the 5\% conventional level of significance, which suggests that these variables satisfy the requirement for valid instruments and are not uncorrelated with the dependent variables. Another issue is whether the instruments

are significant in explaining the extent of local revenue autonomy. The reported Anderson Canon 45

p-values confirm that the instruments explain significantly the fiscal decentralization measured 47 here by local revenue autonomy. The instruments are globally relevant. The statistical significance of the coefficients on the excluded variables in the first-stage estimates was derived $^{17}$.

\footnotetext{
${ }^{17}$ The results (first step regression) are available on request.
} 


\section{Robustness checks}

The benchmark results (column 2, table 2) are not sensitive to the inclusion of other covariates such as the heterogeneity measures and the conflict variables. For example, the effect of local revenue on MPIa does not disappears no matter which measure of heterogeneity is included in the regression and the statistical significance remains for almost all specifications (columns 3 to

6, table 2). However, this statistical significance does not hold in many specifications for the 13 effect on HPIn (columns 7 to 12, table 2).

The above estimations may be sensitive to the inclusion of alternative control variables such as 18 local GDP and other proxy of local heterogeneity ${ }^{18}$. As a robustness check, the estimations

results controlling for local GDP and horizontal inequality is reported in table 6 using both 23 individual fixed effect method and group fixed effect approach, as well. Yet, local revenue autonomy contributes to increase access to public services, confirming that the findings are robust to different specifications. Interestingly, the coefficient for local revenue autonomy result 30 obtained with individual fixed effect (column 3) are not statistically significant giving credence to the GFE approach and that is more efficient. The results are also robust to the inclusion of horizontal inequality as measure of heterogeneity (column 5).

\footnotetext{
${ }^{18}$ The index calculated as: Horizontal Income Inequality $=1-\ln \left(Y_{\text {worst }}\right) / \ln \left(Y_{\text {best }}\right)$. It measures inequality between the richest and the poorest ethnic group.
} 
Another concern relates to the sensibility of the estimations to alternative the level of cutoff 47

thus re-estimate, using $40 \%$ and $20 \%$ as thresholds. As shown in Tables 7, previous results are 52 considered to define a person as deprived of access to public service. The main specifications are

\section{[TABLE 7]}

The analysis goes further by examining whether the 2007 peace agreement signing boosted the 10 implementation program of public services delivery, which may not have been fully captured by

grouped fixed effect. I proceed by dividing the sample into two sub-sample periods: 2001-2006 15 and 2007-2011 and replicate the specification of table 2. This does not alter the previous

findings. Local revenue autonomy positively affects access to public services across the two sub20 periods. However, the results suggest that the effect is higher for the period (2007-2011), after

the signing of the agreement, than the period before the signing (2001-2007) (Table 8). In Côte 25 
d'Ivoire, the 2007 peace agreement was signed by all political parties in the country, and marked 27

\title{
5. Conclusion
}

Providing local governments with decision making and revenue raising responsibilities enhances 46 accountability and thereby increases social welfare through efficient public services delivery 48 (Oates, 1993). The study poses two questions. First, does the effect of fiscal decentralization, using the 2002 and 2008 Household Living Standard Surveys are calculated.

\section{[TABLE 8]}

\begin{abstract}
role played by the local heterogeneity in this relationship.
The empirical study uses the GFE model of Bonhomme \& Manresa (2015) and a local government revenue dataset spanning 11 years (2001-2011) for 115 municipalities in 35 départements. An adjusted multidimensional poverty index and a headcount poverty index at départements level either the access to public services or the poverty in Côte d'Ivoire. The second is relative to the
\end{abstract}


The results suggest that devolving municipality revenue mobilization positively affects the

access to public services and reduces poverty. However, there is evidence that fiscal 13

decentralization has more robust effect on access to public service, than on poverty. This effect

seems to work mainly through enhancing access to education, rather than health, water and 18

sanitation services. Interestingly, the results indicate that municipalities are more likely to

improve access to public services in less ethnically diverse localities and in rural zones. The 23 study provides evidence of the effect of the conflict experienced by the country has been

statistically limited.

This study provides some important implications for the design of anti-poverty programs and 30 fiscal decentralization in Côte d'Ivoire and more broadly in Sub-Saharan Africa. Since several

countries consider fiscal decentralization as a key part of their fiscal reforms, the positive 35

findings concerning the impact of local revenue autonomy in the analysis legitimate and give

more credence to this policy objective. Moreover, the research highlights the importance of the 40 context (rural or urban), and the dimensions of access to public service in which municipalities

may be more effective, and reveals the importance of considering the multiple dimensions of public services as shown by World Bank (2016). 47

From the policy perspective, this is crucial for both policy makers and researcher focusing on

local government autonomy. However, there is a need to construct more accurate 52 
decentralization indicators which reflects the real decision-making power devolved to local authorities. These indicators might include the power to set tax rates, and the political and 
1 institutional processes that assign the responsibility to raise taxes and undertake public spending

Lessmann

$\&$

Markwardt,

(2012). 


\section{References}

Alesina, A., Baqir, R., \& Easterly, W. (1999). Public Goods and Ethnic Divisions. The Quarterly Journal of Economics, 114(4), 1243-1284.

Alesina, A., Devleeschauwer, A., Easterly, W., Kurlat, S., \& Wacziarg, R. (2003). Fractionalization. Journal of Economic Growth, 8(2), 155-194.

Alkire, S., \& Foster, J. (2011). Understandings and misunderstandings of multidimensional poverty measurement. Journal of Economic Inequality, 9(2), 289-314.

Alkire, S., \& Santos, M. (2010). Acute Multidimensional Poverty: A New Index for Developing Countries. SSRN 16 Electronic Journal.

Alkire, S., \& Santos, M. E. (2014). Measuring Acute Poverty in the Developing World: Robustness and Scope of the Multidimensional Poverty Index. World Development, 251-274. https://doi.org/10.1016/j.worlddev.2014.01.026

Bahiigwa, G., Rigby, D., \& Woodhouse, P. (2005). Right target, wrong mechanism? Agricultural modernization and 26 poverty reduction in Uganda. World Development, 33(3), 481-496. https://doi.org/10.1016/j.worlddev.2004.09.008

Bardhan, P. (2002). Decentralization of Governance and Development. Journal of Economic Perspectives, 16(4), 32 185-205. https://doi.org/10.1257/089533002320951037

Bardhan, P., \& Mookherjee, D. (2000). Capture and Governance at Local and National Levels. American Economic 36 Review, 90(2), 135-139. 38 
Bardhan, P., \& Mookherjee, D. (2005). Decentralizing antipoverty program delivery in developing countries. Journal of Public Economics, 89(4), 675-704.

Bargain, O., Donni, O., \& Kwenda, P. (2014). Intrahousehold distribution and poverty: Evidence from Côte d'Ivoire. Journal of Development Economics, 107, 262-276.

Bartolucci, F., Belotti, F., \& Peracchi, F. (2015). Testing for time-invariant unobserved heterogeneity in generalized linear models for panel data. Journal of Econometrics, 184(1), 111-123.

Besley, T., \& Coate, S. (2003). Centralized versus decentralized provision of local public goods: A political economy approach. Journal of Public Economics, 87(12), 2611-2637. https://doi.org/10.1016/S00472727(02)00141-X

Bird, R. M., \& Smart, M. (2002). Intergovernmental fiscal transfers: International lessons for developing countries. World Development, 30(6), 899-912.

Bird, R. M., \& Vaillancourt, F. (2006). Perspectives on Fiscal Federalism. (F. Vaillancourt \& R. Bird, Eds.) (Bird and V). The World Bank Learning ressources series perspectives.

Bird, R., \& Rodriguez, E. (1999). Decentralization and Poverty Alleviation: International Experience and the Case of the Phillipines. Public Administration and Development, 319(19), $299-319$. https://doi.org/10.1002/(SICI)1099-162X(199908)19

Bonhomme, S., \& Manresa, E. (2015). Grouped Patterns of Heterogeneity in Panel Data. Econometrica, 83(3), 
$1147-1184$.

Bracco, E., Lockwood, B., Porcelli, F., \& Redoano, M. (2015). Intergovernmental grants as signals and the alignment effect: Theory and evidence. Journal of Public Economics, 123, 78-91. https://doi.org/10.1016/j.jpubeco.2014.11.007 21

Brun, J.-F., \& Sanogo, T. (2017). Effect of central transfers on municipalities 'own revenue mobilization : Do conflict and local revenue management matter? CERDI: Études et Documents n ${ }^{\circ} 16$.

Caldeira, E., Martial, F., \& Rota-Graziozi, G. (2012). Does decentralization facilitate access to perverty-related services ?Evidence from Benin. Nber Working Paper Series. 29

Caldeira, E., \& Rota-Graziosi, G. (2014). The Crowding-in Effect of Simple Unconditional Central Grants on Local Own-Source Revenue: The Case of Benin. Journal of African Economies, 23(3), 361-387.

Cavalieri, M., \& Ferrante, L. (2016). Does fiscal decentralization improve health outcomes? Evidence from infant mortality in Italy. Social Science \& Medicine, 164, 74-88. https://doi.org/10.1016/j.socscimed.2016.07.017 37 Cristian, S., \& Martinez-Vazquez, J. (2011). The consequences of fiscal decentralization on poverty and income 39 equality. Environment and Planning C: Government and Policy, 29(2), 321-343.

Dabalen, A., Kebede, E., \& Paul, S. (2012). Households in Conflict Network Massive Civilian Displacement in Civil War. HiCN Working Paper 118. (HiCN, Ed.). HiCN Working Paper 118: HiCN Working Paper 118.

Deaton, A. (1997). The analysis of household surveys: A microeconometric approach to development policy. (T. J.

H. U. Press, Ed.), The analysis of household surveys: A microeconometric approach to development policy 49

(Washington). The World Bank. https://doi.org/doi:10.1596/0-8018-5254-4 51

Donnelly-Roark, P., Ouedraogo, K., \& Ye, X. (2001). Can local institutions reduce poverty? Rural decentralization 
in Burkina Faso. The World Bank Policy Research Working Paper, 2677.

Faguet, J.-P. (2014). Decentralization and governance in Ghana. World Developement, 53(2), $2-13$.

Faguet, J.-P., \& Sánchez, F. (2008). Dec

entralization's Effects on Educational Outcomes in Bolivia and Colombia. World Development, 36(7), 1294-1316. https://doi.org/10.1016/j.worlddev.2007.06.021

Francis, P., \& James, R. (2003). Balancing Rural Poverty Reduction and Citizen Participation: The Contradictions of Uganda s Decentralization Program. World Development, 31(2), 325-337.

Furst, T., Tschannen, A., Raso, G., Acka, C., DeSavigny, D., Girardin, O., ... Utzinger, J. (2010). Effect of an armed conflict on relative socioeconomic position of rural households: case study from western Cote d'Ivoire. Emerging Themes in Epidemiology, 7(1), 6.

Galiani, S., Gertler, P., \& Schargrodsky, E. (2008). School decentralization: Helping the good get better, but leaving the poor behind. Journal of Public Economics, 92(10-11), 2106-2120.

https://doi.org/10.1016/j.jpubeco.2008.05.004 19

Gonçalves, S. (2014). The Effects of Participatory Budgeting on Municipal Expenditures and Infant Mortality in 21 Brazil. World Development, 53, 94-110.

Gradstein, M. (2017). Government decentralization as a commitment in non-democracies. Journal of Comparative Economics, 45(1), 110-118. https://doi.org/10.1016/j.jce.2016.01.005 27

Grisorio, M. J., \& Prota, F. (2015). The short and the long run relationship between fiscal decentralization and public expenditure composition in Italy. Economics Letters, 130, 113-116. https://doi.org/10.1016/j.econlet.2015.03.021 33

Hayek, F. K. (1945). The Use of Knowledge in Society. American Economic Review, 35(4), 519-530. 
Heller, P., Harilal, K. N., \& Chaudhuri, S. (2007). Building Local Democracy: Evaluating the Impact of 37 Decentralization in Kerala, India. World Development, 35(4), 626-648. 39

Hindriks, J., Peralta, S., \& Weber, S. (2008). Competing in taxes and investment under fiscal equalization. Journal of Public Economics, 92(12), 2392-2402. https://doi.org/10.1016/j.jpubeco.2007.11.012 43

Hlepas, N. (2013). Cultural Diversity and National Performance Cultural Diversity and National Performance. WP5 / 06 Search Working Paper, Illinois State University. WP5 / 06 Search Working Paper.

[dataset] HLSS. (2002). Enquête sur le niveau de Vie des Ménages de Côte d'Ivoire, Institut National des Statistiques (INS).

[dataset] HLSS. (2008). Enquête sur le Niveau de Vie des Ménages de Côte d'Ivoire, Institut National des Statistiques (INS).

[dataset] HLSS. (2015). Enquête sur le Niveau de Vie des Ménages de Côte d'Tvoire, Institut National des Statistiques (INS).

Kis-Katos, K., \& Sjahrir, B. S. (2017). The impact of fiscal and political decentralization on local public investment in Indonesia. Journal of Comparative Economics, 45(2), 344-365. https://doi.org/10.1016/j.jce.2017.03.003

Knight, B. (2002). Endogenous Federal Grants and Crowd-out of State Government Spending: Theory and Evidence from the Federal Highway Aid Program. The American Economic Review, 92(1), 71-92.

Lee, Y., \& Gordon, R. H. (2005). Tax structure and economic growth. Journal of Public Economics, 89(5), 10271043.

Lessmann, C., \& Markwardt, G. (2012). Aid, Growth and Devolution. World Development, 40(9), $1723-1749$. 
Martinez-Vasquez, J., Vulovic, V., \& Liu, Y. (2011). Direct versus Indirect Taxation: Trends, Theory, and Economic Significance. Georgia State University. International Studies Program., 09-11, 37-92.

Martinez-Vazquez, J., \& McNab, R. M. (2003). Fiscal decentralization and economic growth. World Development, 31(9), 1597-1616.

Minoiu, C., \& Shemyakina, O. N. (2014). Armed conflict, household victimization, and child health in Côte 23 d'Ivoire. Journal of Development Economics, 108, 237-255.

Montalvo, J. G., \& Reynal-Querol, M. (2005). Ethnic diversity and economic development. Journal of Development Economics, 76(2), 293-323.

Montalvo, J. G., \& Reynal-Querol, M. (2005). Ethnic polarization, potential conflict, and civil wars. American Economic Review, 95(3), 796-816.

Murshed, M., \& Tadjoeddin, M. (2009). Revisiting the greed and grievance explanations for violent internal 35 conflict. Journal of International Development, 96(1), 10-14. https://doi.org/10.1002/jid 37

Oates, W. E. (1993a). Fiscal Decentralisation and Economic Development. National Tax Journal, 46(2), $237-243$.

Oates, W. E. (1993b). Fiscal Decentralisation and Economic Development. National Tax Journal, 46(2), $237-243$.

Olken, B. A. (2007). Monitoring Corruption: Evidence from a Field Experiment in Indonesia. Journal of Political Economy, 115(2), 200-249. https://doi.org/10.1086/517935 45

Prud'homme. (1995). The Dangers of Decentralization. The World Bank Research Observer, 30, 2012.

[dataset] Raleigh, C., Linke, A., Hegre, H., \& Karlsen, J. (2010). Introducing ACLED: An Armed Conflict Location 
and Event Dataset: Special Data Feature. Journal of Peace Research, 47(5), 651-660.

Ramírez, J. M., Díaz, Y., \& Bedoya, J. G. (2017). Property Tax Revenues and Multidimensional Poverty Reduction Colombia: A Apatial Approach. World Development, 94, 406-421. https://doi.org/10.1016/j.worlddev.2017.02.005

Reinikka, R., \& Svensson, J. (2004). Local Capture: Evidence from a Central Government Transfer Program in Uganda. The Quarterly Journal of Economics, 119(2), 679-705. https://doi.org/10.1162/0033553041382120

Rodríguez-Pose, A., \& Ezcurra, R. (2010). Does decentralization matter for regional disparities? A cross-country analysis. Journal of Economic Geography, 10(5), 619-644. https://doi.org/10.1093/jeg/lbp049

Sen, A. (1999). The Possibility of Social Choice Amartya Sen. The American Economic Review, 89(3), 349-378.

Smoke, P. (2001). Fiscal Decentralization in Developing Countries A Review of Current Concepts and Practice. United Nations Research Institute for Social Development.

Tiebout, C. (1959). A Pure Theory of Local Expenditures. The Journal of Political Economy, 64(5), 416-424. https://doi.org/10.1086/257839

Tranchant, J. (2007). Decentralization and Ethnic Conflict : The Role of Empowerment Decentralization and 17 Conflict: An Overview (Working Papers No. 5). Clermont-Ferrand. 19

Treisman, D. (2000). The Causes of Corruption: a Cross-National Study. Journal of Public Economics, 76, $399-457$.

von Braun, J., \& Grote, U. (2000). Does Decentralization Serve the Poor? ZEF Working Paper, Bonn, Germany.

Weingast, B. (2014). Second Generation Fiscal Federalism: Political Aspects of Decentralization and Economic

Development. World Development, 53, 14-25. 27

West, L. A., \& Wong, C. P. W. (1995). Fiscal Decentralization and Growing Regional Disparities in Rural China: 29 Some Evidence in the Provision of Social Services. Oxford Review of Economic Policy, 11(4), 70-84. 
https://doi.org/10.1093/oxrep/11.4.70

World Bank. (2016). World Development Indicators : Featuring the Sustainable Development Goals. The World 35 Bank, 46. 
$1 \quad$ Appendix A

2 Table A1 : Descriptive statistics

\begin{tabular}{|c|c|c|c|c|c|c|c|c|c|}
\hline \multirow{2}{*}{ Variables } & \multicolumn{5}{|c|}{ ALL Sample } & \multicolumn{2}{|c|}{ Northern localities } & \multicolumn{2}{|c|}{ Southern localities } \\
\hline & Obs & Mean & Std. Dev. & Min & Max & Mean & Std. Dev. & Mean & Std. Dev. \\
\hline Population & 385 & 98190.00 & 116880.00 & 15086.00 & 758178.0 & 126560.00 & 180587.00 & 85188.00 & 67276.0 \\
\hline Poverty headcount index (HPIn) & 385 & 0.38 & 0.16 & 0.07 & 0.76 & 0.42 & 0.18 & 0.36 & 0.14 \\
\hline Multidimensional poverty index (MPIa) & 385 & 0.28 & 0.10 & 0.08 & 0.51 & 0.34 & 0.08 & 0.26 & 0.09 \\
\hline MPIa_Education & 385 & 0.35 & 0.08 & 0.22 & 0.57 & 0.35 & 0.06 & 0.35 & 0.09 \\
\hline MPIa_Health & 385 & 0.28 & 0.17 & 0.02 & 0.55 & 0.26 & 0.17 & 0.29 & 0.17 \\
\hline MPIa_Water & 385 & 0.15 & 0.06 & 0.00 & 0.38 & 0.17 & 0.07 & 0.14 & 0.06 \\
\hline MPIa_Living standard & 385 & 0.35 & 0.11 & 0.14 & 0.61 & 0.37 & 0.12 & 0.35 & 0.11 \\
\hline Informal (share of informal sector) & 380 & 0.61 & 0.10 & 0.09 & 0.70 & 0.62 & 0.09 & 0.61 & 0.10 \\
\hline Ethnic fractionalization & 311 & 0.66 & 0.20 & 0.13 & 0.99 & 0.59 & 0.24 & 0.68 & 0.17 \\
\hline Ethnic Polarization & 311 & 0.81 & 0.33 & 0.06 & 0.83 & 0.76 & 0.26 & 0.83 & 0.36 \\
\hline Horizontal Inequality & 385 & 0.96 & 0.04 & 0.71 & 0.99 & 0.97 & 0.02 & 0.95 & 0.05 \\
\hline Urban (share of urban population) & 352 & 0.45 & 0.23 & 0.07 & 1.00 & 0.45 & 0.16 & 0.43 & 0.26 \\
\hline Conflict Events (number of events) & 385 & 5.99 & 9.36 & 1.00 & 54.00 & 4.74 & 5.14 & 6.57 & 10.71 \\
\hline Conflict weighted with fatality index & 378 & 899.48 & 4264.63 & 0.00 & 43578.00 & 63.59 & 312.92 & 1260.43 & 5059.12 \\
\hline Household annual consumption (fcfa) & 385 & 930755.9 & 545811.00 & 204843.60 & 1910229.0 & 841559.20 & 521151.10 & 971637.70 & 552910.0 \\
\hline Local Tax Revenue & 303 & 0.25 & 0.21 & 0.00 & 1.00 & 0.11 & 0.20 & 0.28 & 0.20 \\
\hline Local Non-Tax-Revenue & 303 & 0.19 & 0.17 & 0.00 & 0.92 & 0.07 & 0.11 & 0.22 & 0.17 \\
\hline Central transfers & 303 & 0.46 & 0.29 & 0.00 & 1.00 & 0.70 & 0.26 & 0.40 & 0.27 \\
\hline Miscellaneous revenue & 303 & 0.09 & 0.13 & 0.00 & 0.84 & 0.11 & 0.16 & 0.09 & 0.12 \\
\hline
\end{tabular}

3

4

5 Table A2: Bayesian Information Criterion and the optimal number of groups 6

\begin{tabular}{cccccc}
\hline Groups & Obs & BIC & Objective function & Coefficient estimated & Standard errors bootstrapped \\
\hline 1 & 385 & 0.69 & - & - & - \\
2 & 385 & 0.64 & 52.93 & 0.066 & 0.96 \\
3 & 385 & 0.50 & 37.28 & 0.102 & 0.87 \\
$\mathbf{4}$ & $\mathbf{3 8 5}$ & $\mathbf{0 . 2 4}$ & $\mathbf{2 3 . 2 7}$ & $\mathbf{0 . 2 5 9 ^ { \star \star }}$ & $\mathbf{0 . 9 0}$
\end{tabular}



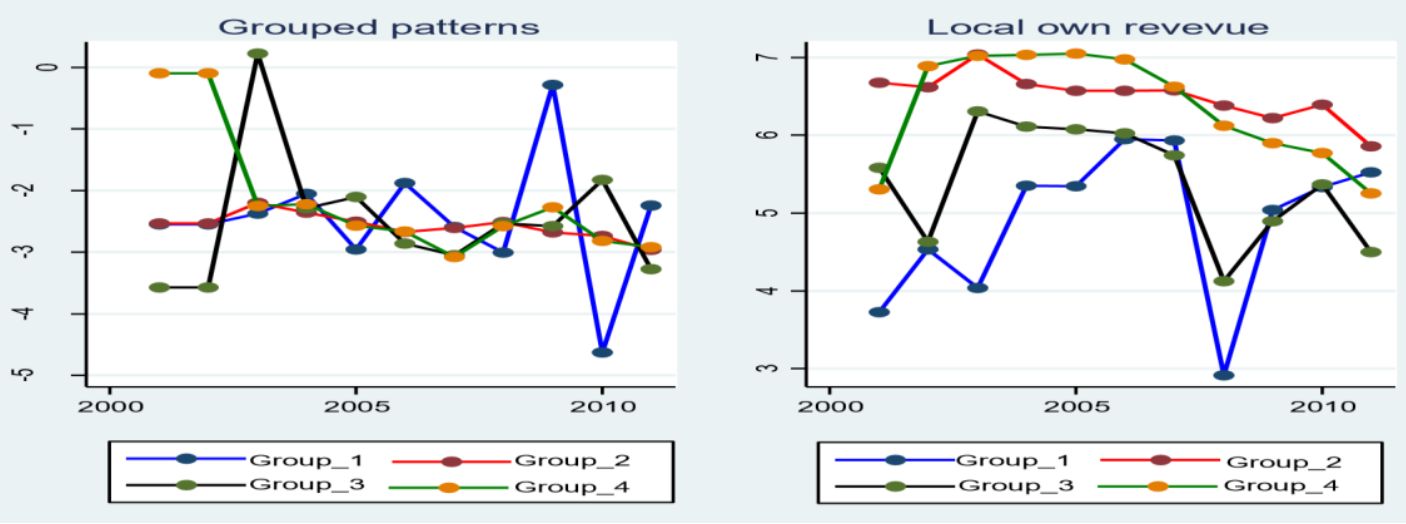

10 Source: Author

11 Figure A1: Group-specific time effects

12 Table A3. Main variables

Adjusted Multidimensional poverty index (MPIa)

MPIa_Education

MPIa_Health

MPIa_Water

MPIa_Living standard

Poverty headcount index
For each département, the percentage of people who are deprived of public services as a percentage of total population. A cutoff of $30 \%$ is used to define a poor individual. Thus a person is poor if the weighted indicators in which he or she is deprived sum up to $30 \%$ or more, as suggested by Alkire \& Santos (2010)

For each département, the number of people who are deprived of education services as a percentage of total population. A cutoff of $30 \%$ is used to define a deprived individual.

For each département, the percentage of people who are deprived of Health services to total population. A cutoff of $30 \%$ is used to define a poor

For each département, the number of people who are deprived of clean water as a percentage of total population.

A cutoff of $30 \%$ is used to define a deprived individual

For each département, the number of people who are deprived of a set of basic living standards of total population. A cutoff of $30 \%$ is used to define a deprived individual

For each département, the percentage of the population living with less than US \$ 1 a day
The 2002 and 2008

Household Living

Standard Surveys

(HLSS), Ministry of Interior Côte d'Ivoire 
Ethnic fractionalization

Ethnic Polarization

Conflict Events

Conflict Events weighted

Local revenue autonomy
The probability that two randomly selected individuals in a département will not belong to the same ethnic group. The higher this index is, the stronger is the heterogeneity of demand.

How far the distribution of the ethnic groups is from the bipolar distribution in a département. The higher this index is, the stronger is the heterogeneity of demand

The share of local businesses not registered with the tax administration

The number of conflict events by département

The number of conflict events weighted with a fatality index of each event by département. The fatality index reports the number of deaths due to each event, one represents least violence and 10 represents the highest incidence of violence

The ratio of local own revenues to total revenues.
The Armed Conflict

Location and Event

Dataset (ACLED)

(Raleigh et al., 2010).

Ministry of interior Côte

d'Ivoire 


\section{$\underline{\text { Figures and Tables }}$}

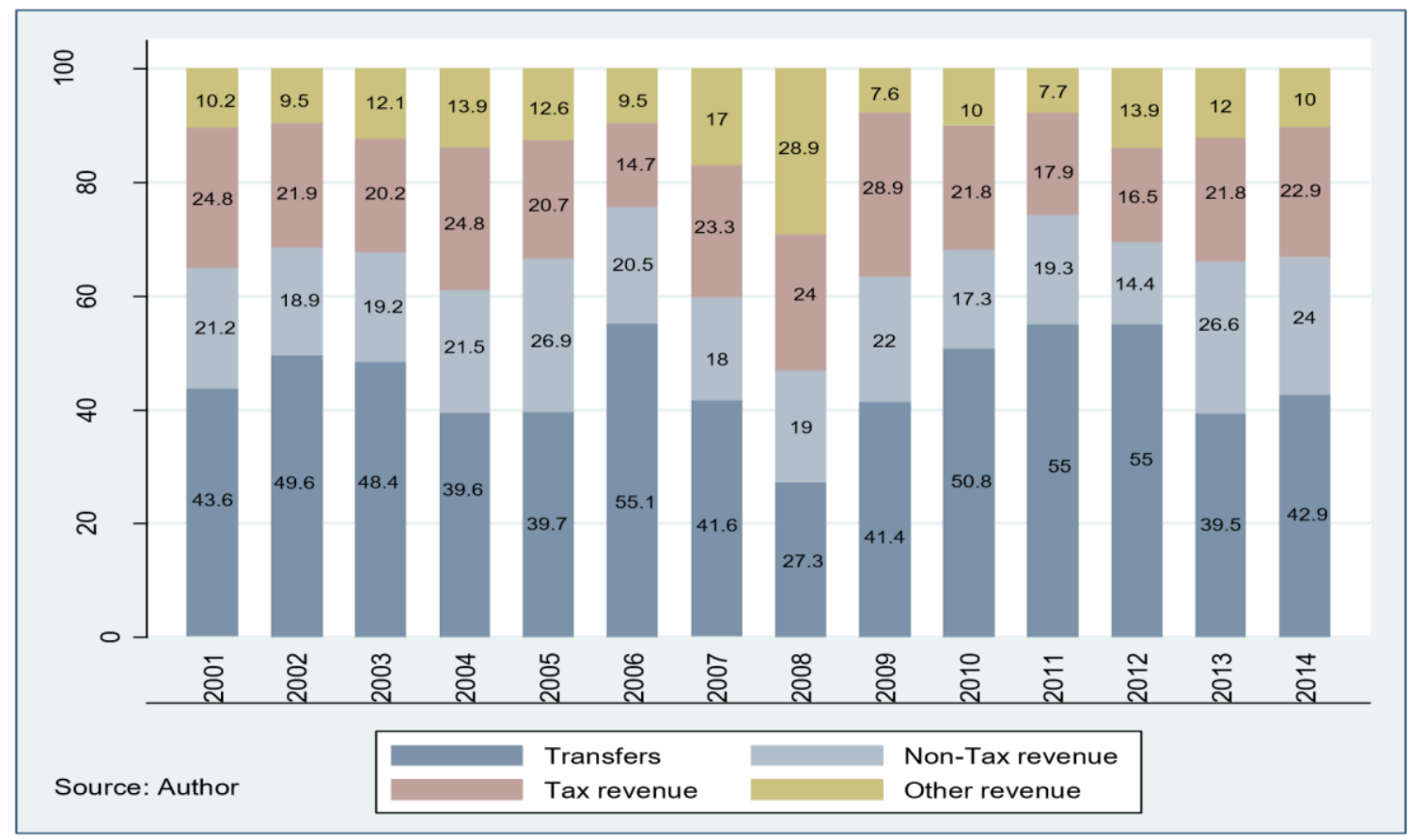

Figure 1: Composition of municipality revenue in Côte d'Ivoire 2001-2014

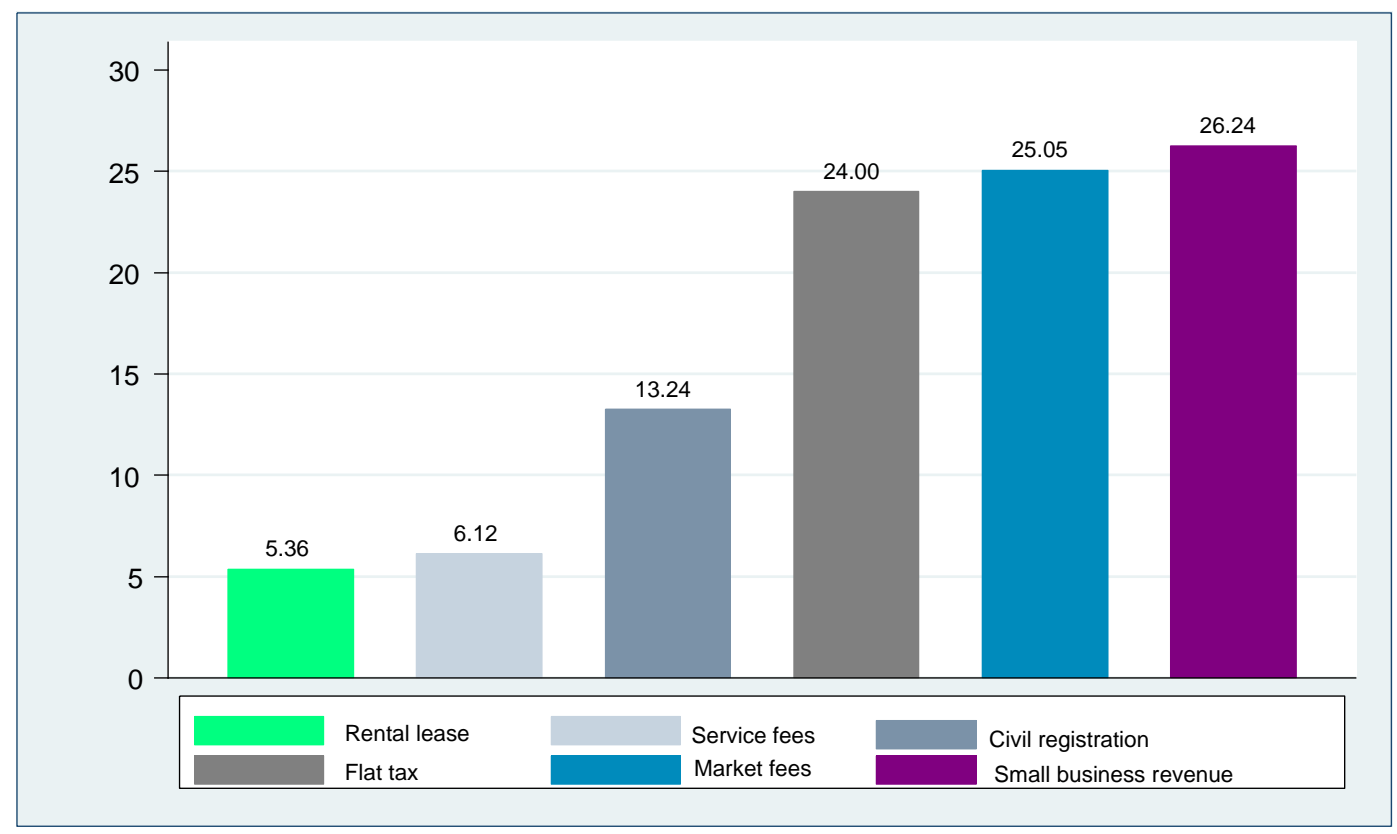

Source: By author with Côte d'Ivoire data from the Ministry of Interior.

Figure 2 : Structure of local non-tax revenue Côte d'Ivoire, 2002-2007. 
Poverty headcount index

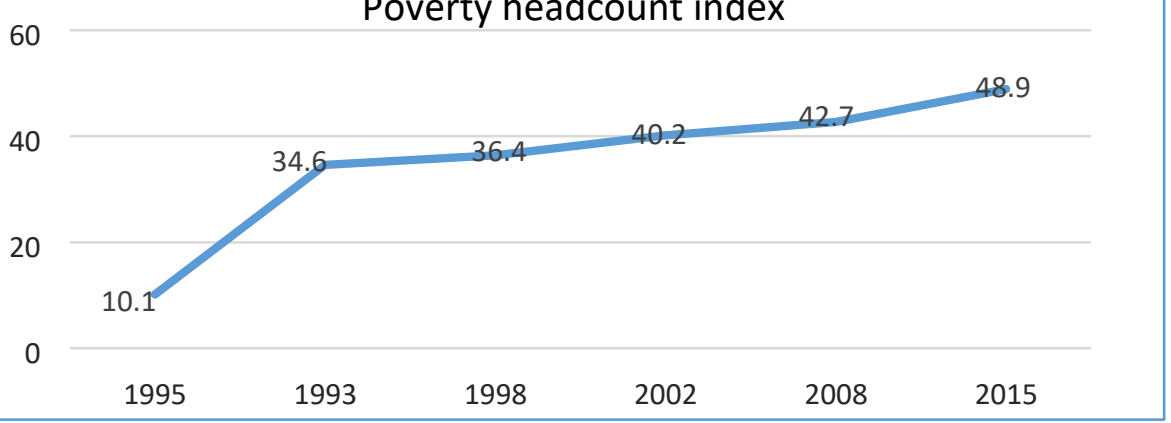

Note: The poverty line in CFAF-75,000 per capita annually in 1985, 101, 340 in 1993, 144, 800 in 1995 and 162, 800 in 1998 Source: Author with data from the World Bank

Figure 3: Poverty Headcount Ratio at national poverty line (\% of population)

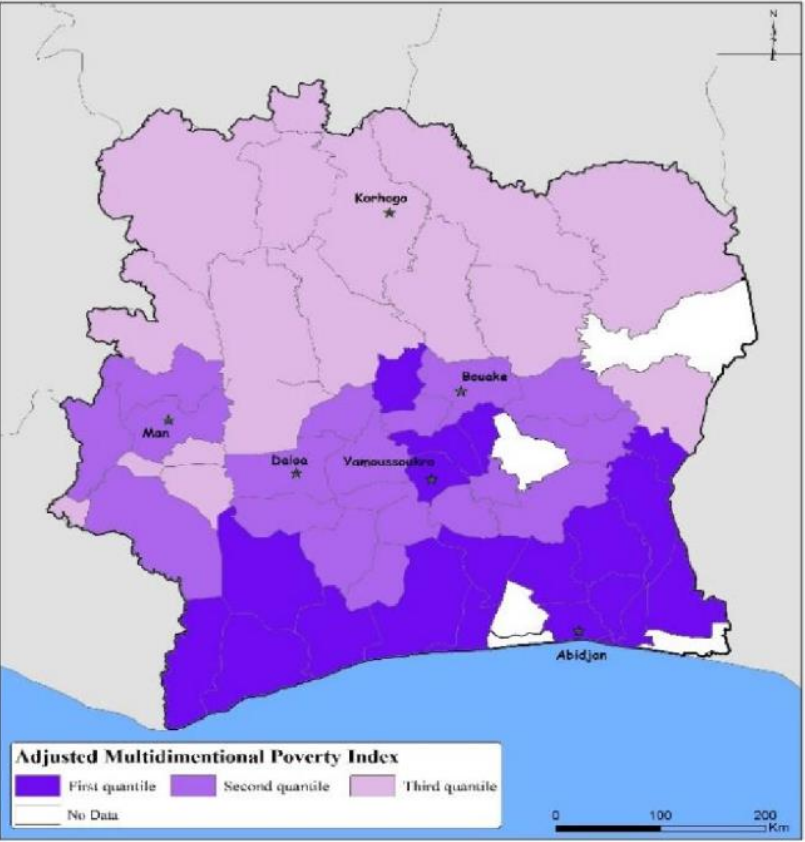

Figure 4: Adjusted Multidimensional Poverty Index

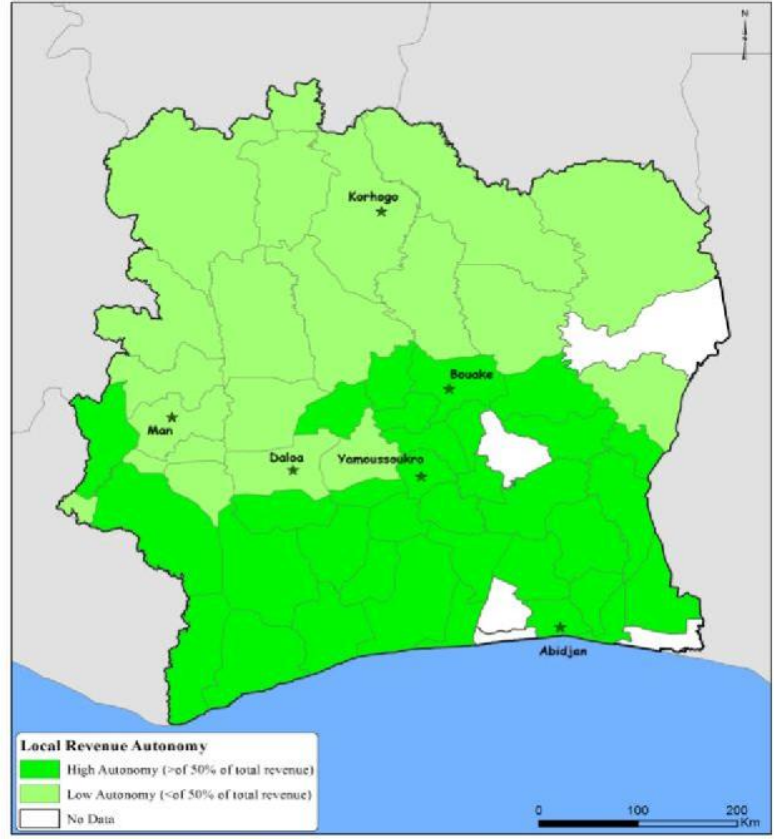

Figure 5: Local Own Revenue distribution pattern (As
Source: A uthor distribution pattern in Côte from the Household Living Standard Surveys (HLSSd'Ivoire, 2008 -

Source:

Author with Côte d'Ivoire data from the Ministry of Interior \% of Total Local Revenue), 2010-2013

2008).

$(D G D D L)$ 


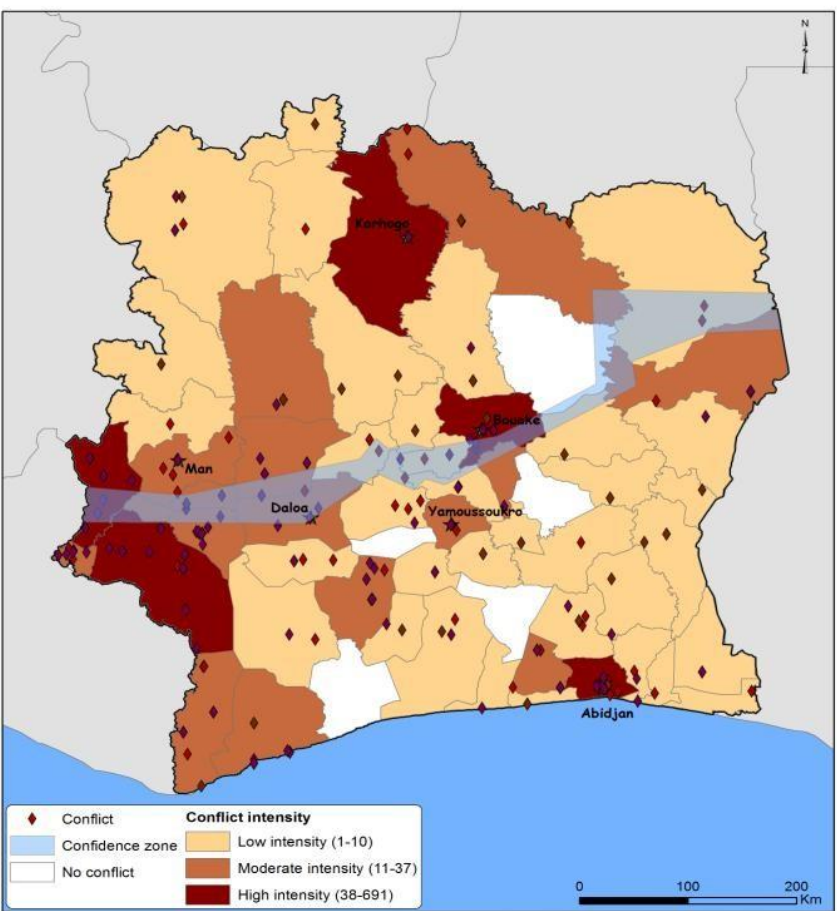

Note:

Figure 4: The Adjusted Multidimensional Poverty Index

(MPIa) is calculated by multiplying the incidence of poverty by the average intensity of poverty across the

poor; as a result, it reflects both the share of people in poverty and the degree by which they are deprived. See more details in the following section. Darker shades indicate a lower poverty index reported as a ratio of the number of multidimensional poor to the total local population.

Figure 5: The local own revenue is calculated as the share of revenue collected by local governments over the total local revenue (It is the mean of four years after conflict,

2010, 2011, 2012 and 2013). Darker shades indicate a higher autonomy of internal revenue collection.

Figure 6: The map depicts conflict regions; dark shades

indicate more intensity conflict such as violence against

civilians, battles, and riots reported in ACLED. The blue

Figure 6: The distribution of violence against civilians and part indicates the confidence zone which divided the the confidence zone 
47 Table 1: Dimensions and indicators used for the MPIa

\begin{tabular}{|c|c|c|c|}
\hline Dimensions & Indicators & $\begin{array}{l}\text { Relative } \\
\text { Weight* }\end{array}$ & Deprived if... \\
\hline \multirow{2}{*}{ Education } & Adult illiteracy & $16.7 \%$ & $\begin{array}{l}\text { The person is not able to read nor write a short simple statement } \\
\text { on his everyday life }\end{array}$ \\
\hline & $\begin{array}{l}\text { No access to } \\
\text { Education }\end{array}$ & $16.7 \%$ & $\begin{array}{l}\text { School-aged child is not attending school in years } 1 \text { to } 8 \text { because } \\
\text { of school remoteness or absence }\end{array}$ \\
\hline \multirow{2}{*}{ Health } & \multirow{2}{*}{$\begin{array}{l}\text { Food Access/ } \\
\text { Availability } \\
\text { Access to } \\
\text { health services }\end{array}$} & $16.7 \%$ & The main household food problem is the lunch or the dinner \\
\hline & & $16.7 \%$ & $\begin{array}{l}\text { The household has no access to health services because of } \\
\text { hospital remoteness or absence }\end{array}$ \\
\hline \multirow{6}{*}{$\begin{array}{l}\text { Standard of } \\
\text { Living }\end{array}$} & \multirow{5}{*}{$\begin{array}{l}\text { Sanitation } \\
\text { Electricity } \\
\text { Water Access } \\
\text { Floor } \\
\text { Cooking Fuel }\end{array}$} & $5.6 \%$ & $\begin{array}{l}\text { The household has no access to improved sanitation facilities (No } \\
\text { toilet) }\end{array}$ \\
\hline & & $5.6 \%$ & The household has no access to electricity \\
\hline & & $5.6 \%$ & The household does not have access to clean drinking water \\
\hline & & $5.6 \%$ & The household has dirt, sand or dung floor \\
\hline & & $5.6 \%$ & The household cooks with dung, wood or charcoal \\
\hline & Assets & $5.6 \%$ & $\begin{array}{l}\text { The household does not own more than one of radio, TV, } \\
\text { telephone, bike, motorbike or refrigerator }\end{array}$ \\
\hline
\end{tabular}




\begin{tabular}{|c|c|c|c|c|c|c|c|c|c|c|c|c|}
\hline \multirow[t]{3}{*}{ Dependent variable } & \multicolumn{6}{|c|}{ Multidimensional Poverty Index (MPIa) } & \multicolumn{6}{|c|}{ Headcount poverty Index (HPIn) } \\
\hline & (1) & (2) & (3) & (4) & (5) & (6) & (7) & (8) & (9) & (10) & (11) & (12) \\
\hline & GFE & GFE_IV & GFE_IV & GFE_IV & GFE_IV & GFE_IV & GFE & GFE_IV & GFE_IV & GFE_IV & GFE_IV & GFE_IV \\
\hline LRA & $\begin{array}{c}-0.0856^{* * * *} \\
(0.0224)\end{array}$ & $\begin{array}{c}-0.0949 * * * \\
(0.0265)\end{array}$ & $\begin{array}{c}-0.0706^{* * * *} \\
(0.0266)\end{array}$ & $\begin{array}{c}0.0363 \\
(0.0506)\end{array}$ & $\begin{array}{c}-0.0708^{* * * *} \\
(0.0248)\end{array}$ & $\begin{array}{l}-0.0197 \\
(0.0346)\end{array}$ & $\begin{array}{r}-0.00191 \\
(0.0129)\end{array}$ & $\begin{array}{c}-0.0896^{* *} \\
(0.0445)\end{array}$ & $\begin{array}{l}-0.120^{*} \\
(0.0716)\end{array}$ & $\begin{array}{c}-0.137 \\
(0.0886)\end{array}$ & $\begin{array}{c}-0.117 \\
(0.0791)\end{array}$ & $\begin{array}{l}-0.151 \\
(0.107)\end{array}$ \\
\hline Central Transfers & $\begin{array}{l}-0.0545^{*} \\
(0.0272)\end{array}$ & $\begin{array}{c}-0.0531 * * \\
(0.0253)\end{array}$ & $\begin{array}{c}-0.0763^{* * * *} \\
(0.0275)\end{array}$ & $\begin{array}{c}-0.0474 * * \\
(0.0221)\end{array}$ & $\begin{array}{c}-0.0466^{* *} \\
(0.0230)\end{array}$ & $\begin{array}{l}-0.0229 \\
(0.0234)\end{array}$ & $\begin{array}{c}0.0134 \\
(0.0162)\end{array}$ & $\begin{array}{l}0.00762 \\
(0.0127)\end{array}$ & $\begin{array}{c}0.0104 \\
(0.0130)\end{array}$ & $\begin{array}{c}0.0170 \\
(0.0130)\end{array}$ & $\begin{array}{l}0.00319 \\
(0.0143)\end{array}$ & $\begin{array}{l}0.00924 \\
(0.0146)\end{array}$ \\
\hline Urban population & $\begin{array}{c}-0.732^{* * * *} \\
(0.161)\end{array}$ & $\begin{array}{c}-0.753^{* * * *} \\
(0.190)\end{array}$ & $\begin{array}{c}-0.689^{* * *} \\
(0.213)\end{array}$ & $\begin{array}{c}-0.739 * * * \\
(0.161)\end{array}$ & $\begin{array}{c}-0.636^{* * *} \\
(0.215)\end{array}$ & $\begin{array}{c}-0.690^{* * *} \\
(0.167)\end{array}$ & $\begin{array}{c}-0.145^{* * *} \\
(0.0446)\end{array}$ & $\begin{array}{l}-0.168 \\
(0.145)\end{array}$ & $\begin{array}{c}-0.110 * * * \\
(0.0424)\end{array}$ & $\begin{array}{c}-0.127 * * * \\
(0.0480)\end{array}$ & $\begin{array}{c}-0.143 * * * \\
(0.0464)\end{array}$ & $\begin{array}{c}-0.172^{* * *} \\
(0.0568)\end{array}$ \\
\hline Informal sector & $\begin{array}{c}0.948 * * * \\
(0.257)\end{array}$ & $\begin{array}{c}1.008 * * * \\
(0.262)\end{array}$ & $\begin{array}{c}0.865 * * * \\
(0.289)\end{array}$ & $\begin{array}{c}0.680 * * * \\
(0.263)\end{array}$ & $\begin{array}{c}0.896 * * * \\
(0.324)\end{array}$ & $\begin{array}{c}0.755^{* *} \\
(0.354)\end{array}$ & $\begin{array}{c}-0.555^{* * *} \\
(0.158)\end{array}$ & $\begin{array}{l}-0.598 \\
(0.514)\end{array}$ & $\begin{array}{l}-0.0655 \\
(0.125)\end{array}$ & $\begin{array}{l}-0.0751 \\
(0.127)\end{array}$ & $\begin{array}{l}-0.101 \\
(0.138)\end{array}$ & $\begin{array}{l}-0.113 \\
(0.144)\end{array}$ \\
\hline Ethnic frag & & & -0.109 & $0.333 * *$ & & & & & $-0.238 * * *$ & $-0.597 *$ & & \\
\hline & & & $(0.0857)$ & $(0.138)$ & & & & & $(0.0411)$ & $(0.322)$ & & \\
\hline Ethnic fragmentation*LRA & & & & $-0.114 * * *$ & & & & & & 0.0744 & & \\
\hline & & & & $(0.0399)$ & & & & & & $(0.0658)$ & & \\
\hline Ethnic polarization & & & & & $-0.0934 * *$ & 0.0657 & & & & & -0.00581 & -0.190 \\
\hline & & & & & $(0.0391)$ & $(0.0702)$ & & & & & $(0.0439)$ & $(0.160)$ \\
\hline Ethnic polarization*LRA & & & & & & $-0.0433^{* *}$ & & & & & & 0.0402 \\
\hline & & & & & & $(0.0205)$ & & & & & & $(0.0329)$ \\
\hline Constant & $-1.936 * * *$ & $-1.502 * * *$ & $-1.249 * * *$ & -0.399 & $-1.472 * * *$ & $-1.123 * * *$ & $-0.637 * * *$ & -0.691 & $-1.227 * * *$ & $-1.756^{* * * *}$ & $-1.163 * * *$ & $-1.461 * * *$ \\
\hline Observations & 250 & 182 & 147 & 147 & 147 & 147 & 250 & 182 & 147 & 147 & 147 & 147 \\
\hline
\end{tabular}


R-squared

Hansen (p-value)

Cragg-Donald Wald F statistic

Anderson canon (P-value)

GFE

Départements FE
No
0.829

$$
0.832
$$

0.832
0.08 $\quad 0.830$

0.832
0.08

0.830
0.68

0.859
0.95

0.839

0.839
0.43

0.858
0.1

0.749

$$
126.04
$$

108.03

$25.21 \quad 111.781$

48.43

0.00

0.00

0.00

0.00

0.00

Yes

Yes

Yes

Yes

Yes

Yes

Yes

Yes

Robust standard errors clustered at the départements level in parentheses / *significant at $10 \% ; * *$ significant at $5 \%$; *** significant at $1 \%$ 


\begin{tabular}{|c|c|c|c|c|c|c|c|c|c|c|c|c|}
\hline LRA & $\begin{array}{l}-0.08^{* * * *} \\
(0.02)\end{array}$ & $\begin{array}{l}-0.03^{* * * *} \\
(0.01)\end{array}$ & $\begin{array}{l}-0.13^{* * * *} \\
(0.02)\end{array}$ & $\begin{array}{l}-0.05^{*} \\
(0.03)\end{array}$ & $\begin{array}{l}-0.05^{*} \\
(0.03)\end{array}$ & $\begin{array}{l}-0.09^{* *} \\
(0.03)\end{array}$ & $\begin{array}{l}-0.02 \\
(0.02)\end{array}$ & $\begin{array}{l}-0.01 \\
(0.01)\end{array}$ & $\begin{array}{l}-0.03 \\
(0.06)\end{array}$ & $\begin{array}{l}-0.08^{* *} \\
(0.03)\end{array}$ & $\begin{array}{l}-0.01 \\
(0.01)\end{array}$ & $\begin{array}{l}-0.15^{\text {**** }} \\
(0.03)\end{array}$ \\
\hline lagMPI_Educ & & $\begin{array}{l}0.60 * * * \\
(0.08)\end{array}$ & & & & & & & & & & \\
\hline \multirow[t]{2}{*}{ lagMPI_Heath } & & & & & $0.04 * *$ & & & & & & & \\
\hline & & & & & $(0.017)$ & & & & & & & \\
\hline \multirow[t]{2}{*}{ lagMPI_water } & & & & & & & & $0.38^{* * *}$ & & & & \\
\hline & & & & & & & & $(0.08)$ & & & & \\
\hline \multirow[t]{2}{*}{ lagMPI_living } & & & & & & & & & & & $0.72 * * *$ & \\
\hline & & & & & & & & & & & $(0.069)$ & \\
\hline \multirow[t]{2}{*}{ Central Transfers } & & & -0.032 & & & $-0.068^{*}$ & & & 0.008 & & & $-0.10^{* *}$ \\
\hline & & & $(0.026)$ & & & $(0.035)$ & & & $(0.03)$ & & & $(0.04)$ \\
\hline \multirow[t]{2}{*}{ Urban population } & & & $-0.40^{* * *}$ & & & $-0.32^{*}$ & & & -0.13 & & & $-1.19^{* * * *}$ \\
\hline & & & $(0.08)$ & & & $(0.19)$ & & & $(0.20)$ & & & $(0.20)$ \\
\hline \multirow[t]{2}{*}{ Informal sector } & & & $0.98 * *$ & & & 0.208 & & & -0.011 & & & $2.39 * * *$ \\
\hline & & & $(0.40)$ & & & $(0.361)$ & & & $(0.16)$ & & & $(0.72)$ \\
\hline Constant & $\underline{-2.5^{\star \star \star}}$ & $\underline{-1.01^{* \star *}}$ & $\underline{-3.05 * * *}$ & $\underline{-4.2 * * *}$ & $\underline{-4.0^{* \star *}}$ & $-1.7^{\star \star \star}$ & $\underline{-2.3^{* * *}}$ & $\underline{-1.5^{\star \star \star}}$ & $\underline{-1.9^{* * *}}$ & $\underline{-2.5^{\star \star *}}$ & $\underline{-0.5^{\star \star \star}}$ & $\underline{-3.78 * * *}$ \\
\hline Observations & 277 & 276 & 182 & 277 & 276 & 182 & 272 & 266 & 179 & 277 & 276 & 182 \\
\hline R-squared & 0.55 & 0.79 & 0.66 & 0.93 & 0.93 & 0.94 & 0.71 & 0.80 & 0.67 & 0.65 & 0.70 & 0.60 \\
\hline Hansen (p-value) & & & 0.58 & & & 0.56 & & & 0.13 & & & 0.001 \\
\hline Cragg-Donald Wald & F statistic & & 149.45 & & & 175.80 & & & 155.33 & & & 149.12 \\
\hline Anderson canon (P-v & value) & & 0.004 & & & 0.00 & & & 0.00 & & & 0.00 \\
\hline
\end{tabular}

\begin{tabular}{|c|c|c|c|c|c|c|c|c|c|c|c|c|}
\hline GFE & Yes & Yes & Yes & Yes & Yes & Yes & Yes & Yes & Yes & Yes & Yes & Yes \\
\hline Départements FE & Yes & Yes & Yes & Yes & Yes & Yes & Yes & Yes & Yes & Yes & Yes & Yes \\
\hline $\begin{array}{l}\text { Dependent } \\
\text { variable: }\end{array}$ & \multicolumn{3}{|c|}{ MPI_Education } & \multicolumn{3}{|c|}{ MPI_Health } & \multicolumn{3}{|c|}{ MPI_Water } & \multicolumn{3}{|c|}{ MPI_Living standard } \\
\hline \multirow{2}{*}{$\begin{array}{l}\text { MPIa by } \\
\text { dimension }\end{array}$} & (1) & (2) & (3) & (4) & (5) & (6) & (7) & (8) & (9) & (10) & (11) & (12) \\
\hline & GFE & GFE & GFE_IV & GFE & GFE & GFE_IV & GFE & GFE & GFE_IV & GFE & GFE & GFE \\
\hline
\end{tabular}


Table 4: Effect of LRA on multidimensional poverty index by subgroup: urban and rural population

\begin{tabular}{|c|c|c|c|c|}
\hline \multirow{3}{*}{$\begin{array}{l}\text { Dependent variable: } \\
\text { MPIa for rural and urban } \\
\text { area }\end{array}$} & \multicolumn{2}{|c|}{ MPIa_Rural } & \multicolumn{2}{|c|}{ MPIa_Urban } \\
\hline & (1) & (2) & (3) & (4) \\
\hline & GFE & GFE_2SLS & GFE & GFE_2SLS \\
\hline LRA & $\begin{array}{l}-0.103 * \\
(0.0505)\end{array}$ & $\begin{array}{c}-0.166^{* * *} \\
(0.0594)\end{array}$ & $\begin{array}{c}-0.132 * * * \\
(0.0459)\end{array}$ & $\begin{array}{c}-0.184 * * * \\
(0.0574)\end{array}$ \\
\hline Central Transfers & & -0.0812 & & $-0.128 *$ \\
\hline & & $(0.0700)$ & & $(0.0759)$ \\
\hline Urban population & & $-1.441 * * *$ & & $-1.552 * *$ \\
\hline & & $(0.377)$ & & $(0.699)$ \\
\hline Informal sector & & 0.100 & & 0.0320 \\
\hline & & $(0.251)$ & & $(0.968)$ \\
\hline Constant & $\begin{array}{c}-1.138 * * * \\
(0.0896)\end{array}$ & $\begin{array}{c}0.954 \\
(0.614)\end{array}$ & $\begin{array}{l}-0.595 \\
(0.381)\end{array}$ & $\begin{array}{c}0.558 \\
(1.036)\end{array}$ \\
\hline Observations & 131 & 85 & 174 & 112 \\
\hline R-squared & 0.869 & 0.930 & 0.610 & 0.780 \\
\hline Hansen (p-value) & & 0.20 & & 0.328 \\
\hline Cragg-Donald Wald F statistic & & 29.23 & & 71.81 \\
\hline Anderson canon (P-value) & & 0.00 & & 0.00 \\
\hline GFE & Yes & Yes & Yes & Yes \\
\hline Departement FE & Yes & Yes & Yes & Yes \\
\hline
\end{tabular}


Table 5: Effect of municipal revenue autonomy and conflict on access to basic service and poverty

\begin{tabular}{|c|c|c|c|c|c|c|}
\hline \multirow{3}{*}{ Dependent variable } & \multicolumn{3}{|c|}{ Multidimensional poverty index } & \multicolumn{3}{|c|}{ Headcount poverty Index } \\
\hline & (1) & (2) & (3) & (4) & (5) & (6) \\
\hline & GFE_2SLS & GFE_2SLS & GFE_2SLS & GFE_2SLS & GFE_2SLS & GFE_2SLS \\
\hline \multirow[t]{2}{*}{ LRA } & $-0.121 * * *$ & $-0.128 * * *$ & $-0.0831 * *$ & $-0.0896^{* *}$ & $-0.0865^{* *}$ & -0.186 \\
\hline & $(0.0286)$ & $(0.0267)$ & $(0.0372)$ & $(0.0445)$ & $(0.0421)$ & $(0.133)$ \\
\hline \multirow[t]{2}{*}{ Central Transfers } & -0.0365 & -0.0506 & -0.0152 & 0.00762 & 0.00660 & 0.0112 \\
\hline & $(0.0334)$ & $(0.0328)$ & $(0.0328)$ & $(0.0127)$ & $(0.0129)$ & $(0.0233)$ \\
\hline \multirow[t]{2}{*}{ Urban population } & $-0.983 * * *$ & $-1.015 * * *$ & $-1.024 * * *$ & -0.168 & -0.176 & -0.139 \\
\hline & $(0.0845)$ & $(0.0806)$ & $(0.0792)$ & $(0.145)$ & $(0.151)$ & $(0.205)$ \\
\hline \multirow[t]{2}{*}{ Informal sector } & $0.973^{* *}$ & $1.033^{* *}$ & $0.945^{*}$ & -0.598 & -0.589 & -0.683 \\
\hline & $(0.469)$ & $(0.461)$ & $(0.489)$ & $(0.514)$ & $(0.512)$ & $(0.452)$ \\
\hline \multirow[t]{2}{*}{ Conflict events } & & $-0.0540 * *$ & & & -0.0148 & \\
\hline & & $(0.0250)$ & & & $(0.0137)$ & \\
\hline \multirow[t]{2}{*}{ Conflict events weighted } & & & 0.00477 & & & 0.00985 \\
\hline & & & $(0.0155)$ & & & $(0.0177)$ \\
\hline \multirow[t]{2}{*}{ Constant } & $-1.691 * * *$ & $-1.605 * * *$ & $-1.783^{* * *}$ & -0.691 & -0.686 & $-0.696^{*}$ \\
\hline & $(0.365)$ & $(0.366)$ & $(0.385)$ & $(0.448)$ & $(0.445)$ & $(0.404)$ \\
\hline Observations & 182 & 182 & 148 & 182 & 182 & 148 \\
\hline R-squared & 0.77 & 0.79 & 0.78 & 0.638 & 0.64 & 0.61 \\
\hline Hansen (p-value) & 0.202 & 0.064 & 0.831 & 0.091 & 0.117 & 0.12 \\
\hline Cragg-Donald Wald F statistic & 141.41 & 139.05 & 112.77 & 103.63 & 96.24 & 75.59 \\
\hline Anderson canon (P-value) & 0.00 & 0.00 & 0.00 & 0.00 & 0.00 & 0.00 \\
\hline GFE & Yes & Yes & Yes & Yes & Yes & Yes \\
\hline Departement FE & Yes & Yes & Yes & Yes & Yes & Yes \\
\hline
\end{tabular}


Table 6: Effect of LRA on MPIa, controlling for Département GDP and alternative measure of parentheses /

*significant at $10 \%$; ** significant at 5\%; ***
significant at $1 \%$ heterogeneity

\begin{tabular}{|c|c|c|c|c|c|c|}
\hline \multirow{4}{*}{$\begin{array}{l}\text { Dependent } \\
\text { variable: MPIa }\end{array}$} & (1) & (2) & (3) & (4) & (5) & (6) \\
\hline & \multirow{2}{*}{\multicolumn{4}{|c|}{ Controlling for Département GDP }} & \multicolumn{2}{|c|}{ Controlling for Département GDP } \\
\hline & & & & & \multirow{2}{*}{$\frac{\text { Alternative }}{\text { GFE VI }}$} & \multirow{2}{*}{$\frac{\text { measur heterogeneity }}{\text { GFE VI }}$} \\
\hline & $\overline{\mathrm{FE}}$ & GFE & FE IV & GFE_2SLS & & \\
\hline LRA & $\begin{array}{l}-0.0427^{* *} \\
(0.0193)\end{array}$ & $\begin{array}{l}-0.0627 * * \\
(0.0275)\end{array}$ & $\begin{array}{l}-0.233 \\
(0.175)\end{array}$ & $\begin{array}{l}-0.0842^{* *} \\
(0.0407)\end{array}$ & $\begin{array}{l}-0.0872 * * \\
(0.0414)\end{array}$ & $\begin{array}{c}-1.628 \\
(3.010)\end{array}$ \\
\hline Local_GDPhbt & $\begin{array}{l}0.0137 \\
(0.0254)\end{array}$ & $\begin{array}{l}-0.0801 * * * \\
(0.0278)\end{array}$ & $\begin{array}{l}-0.132 \\
(0.111)\end{array}$ & $\begin{array}{l}-0.0909 * * * \\
(0.0301)\end{array}$ & $\begin{array}{c}-0.0884 * * * \\
(0.0288)\end{array}$ & $\begin{array}{l}-1.616 \\
(3.011)\end{array}$ \\
\hline Urban population & $\begin{array}{l}-0.523 * * \\
(0.221)\end{array}$ & $\begin{array}{l}-0.746^{* * * *} \\
(0.173)\end{array}$ & $\begin{array}{l}-0.423 * \\
(0.244)\end{array}$ & $\begin{array}{l}-0.875 * * * \\
(0.227)\end{array}$ & $\begin{array}{c}-0.871 * * * \\
(0.222)\end{array}$ & $\begin{array}{c}-0.866^{* * * *} \\
(0.234)\end{array}$ \\
\hline Informal sector & $\begin{array}{l}-2.181 * * \\
(0.807)\end{array}$ & $\begin{array}{l}0.622 * \\
(0.332)\end{array}$ & $\begin{array}{l}-2.180 * * \\
(0.862)\end{array}$ & $\begin{array}{l}0.481 \\
(0.452)\end{array}$ & $\begin{array}{c}0.579 \\
(0.490)\end{array}$ & $\begin{array}{c}0.520 \\
(0.446)\end{array}$ \\
\hline \multirow{2}{*}{\multicolumn{2}{|c|}{ Horizontal_inequality }} & & & & -0.365 & -10.21 \\
\hline & & & & & $(0.335)$ & $(19.50)$ \\
\hline \multicolumn{3}{|c|}{ Horizontal-inequality *LRA } & & & & $\begin{array}{c}1.587 \\
(3.111)\end{array}$ \\
\hline Constant & 0.693 & $-1.461 * * *$ & 1.628 & $-0.961 * * *$ & $-1.076^{* * *}$ & $-1.403 * *$ \\
\hline Observations & 256 & 256 & 185 & 185 & 185 & 185 \\
\hline $\begin{array}{l}\text { R-squared } \\
\text { Hansen (p-value }\end{array}$ & 0.574 & 0.828 & $\begin{array}{l}0.772 \\
0.61\end{array}$ & $\begin{array}{l}0.790 \\
0.12\end{array}$ & $\begin{array}{c}0.792 \\
0.15\end{array}$ & $\begin{array}{c}0.735 \\
0.21\end{array}$ \\
\hline Cragg-Donald $\mathrm{V}$ & d F statistic & & 5.41 & 181.54 & 173.42 & 1.60 \\
\hline Anderson canon & -value) & & 0.00 & 0.00 & 0.00 & 0.14 \\
\hline GFE & No & Yes & Yes & Yes & Yes & Yes \\
\hline Departement FE & Yes & Yes & Yes & Yes & Yes & Yes \\
\hline
\end{tabular}

Table 7: Effect of LRA on MPIa, different cutoffs for deprivation

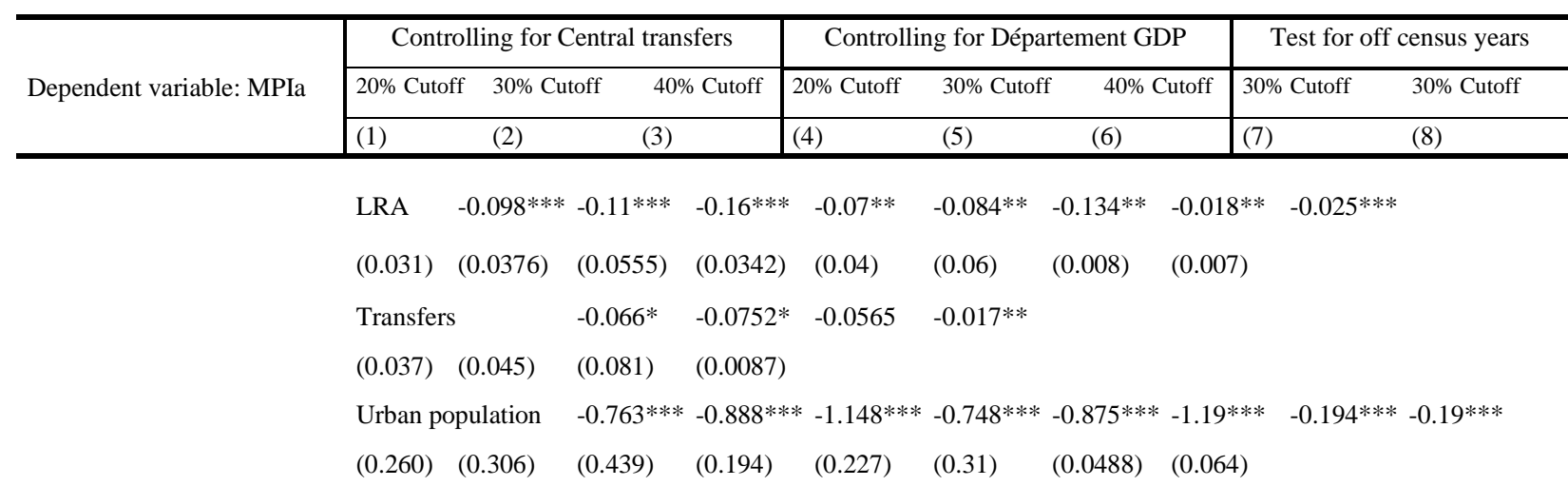

Informal sector $0.5340 .6350 .7820 .3970 .4810 .670 .09500 .13143(0.455)(0.537)(0.820)(0.384)(0.452)(0.66)$ (0.0962) (0.11) 44

$$
\begin{aligned}
& \begin{array}{lllll}
\text { loc_GDPhbt }-0.0788^{* * * *} & -0.09 * * * & -0.11 * * * & -0.0210^{* * *} \\
(0.0255) & (0.03) & (0.042) & (0.00634)
\end{array}
\end{aligned}
$$




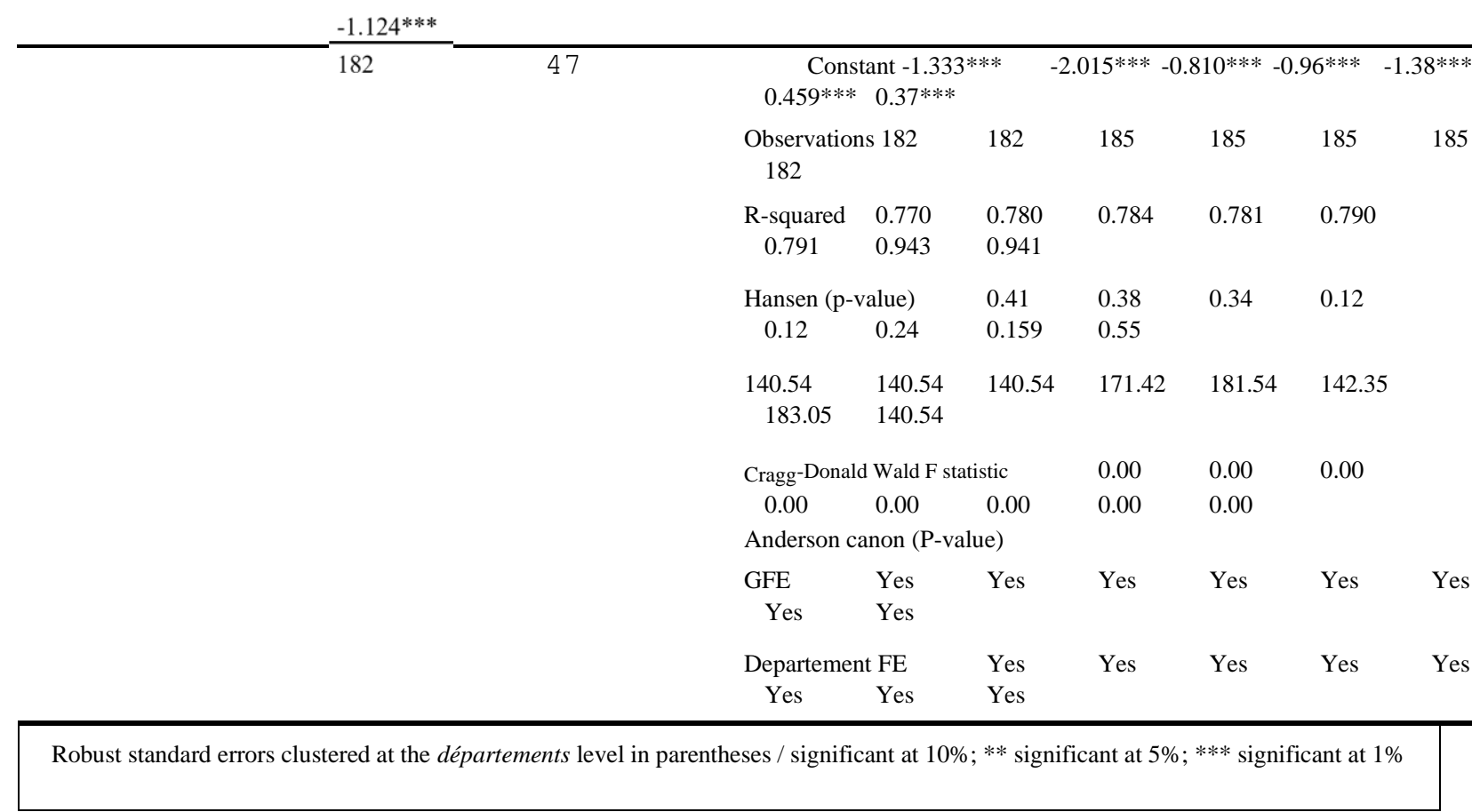

Table 8: Effect of LRA on MPIa, before and after the 2007 peace agreement signing, GFE_2SLS estimation

Before 2007 Peace agreement $\quad$ After 2007 Peace agreement

\begin{tabular}{llllllllr}
\cline { 2 - 8 } & $(1)$ & $(2)$ & $(3)$ & $(4)$ & $(5)$ & $(6)$ & $(7)$ & $(8)$ \\
GFE & GFE & GFE_2SLS & GFE_2SLS & GFE & GFE & GFE_2SLS & GFE_2SLS \\
\hline
\end{tabular}

LRA

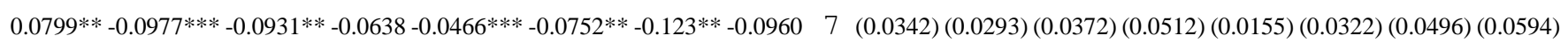

8 Central Transfers $-0.0145-0.0298-0.0546-0.0780-0.0968-0.141 * \quad 9 \quad(0.0357)(0.0342)(0.0364)(0.0579)(0.0638)(0.0737)$

$10 \quad$ Urban population $\quad-0.664 * *-0.791 * * *-0.791 * * *-0.795 * * \quad-0.920 * * *-0.816^{* *}$

$11 \quad(0.241)(0.251)(0.235)(0.302)(0.355)(0.329) 12 \quad$ Informal sector $1.037 * * * 0.977 * * * 0.875 * * 0.4900 .3311 .06913 \quad(0.329)(0.377)$ (0.388) (0.810) (1.018) (1.160)

Ethnic frag.*LRA $\quad-0.0292 \quad 0.000745$

(0.0216) (0.0354)

Grouped fixed effet $0.629 * * * 0.1480 .240 * * 0.328 * * 0.290^{* *} 0.283 *$ $0.290 * 0.278 * 17 \quad(0.104)(0.226)(0.119)(0.142)(0.134)(0.155)$ $(0.149)(0.165)$ 
Hansen (p-value) $\quad 0.0454 \quad 0.08 \quad 0.73 \quad 0.73$

Cragg-Donald Wald F statistic 117.67 71.04 71.07 43.59 24 Anderson canon (P-value) $0.000 .00 \quad 0.000 .00$

\begin{tabular}{lcccccccc} 
GFE & Yes & Yes & Yes & Yes & Yes & Yes & Yes & Yes \\
Departement FE & Yes & Yes & Yes & Yes & Yes & Yes & Yes & Yes \\
\hline
\end{tabular}

Robust standard errors clustered at the départements level in parentheses / *significant at 10\%; ** significant at 5\%; *** significant at $1 \%$ 
'Conflicts of interest: none'

Tiangboho Sanogo

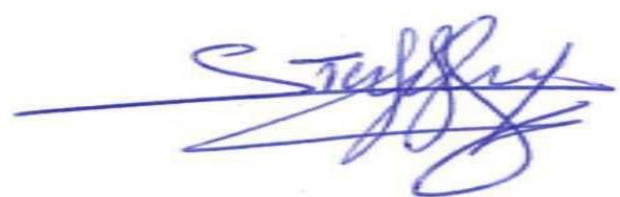

